\title{
The lives of others: selecting the Congolese elite (1948-1956)
}

\section{A question of assimilation: the two-tier évolué status}

His superior's assessment, the many articles in the press and his post as president in multiple associations were testimony to it. The contents of his kitchen and the arrangement of his living room left no room for doubt either: the selection committee was quite clear that they were dealing with a "genuine" évolué. In the summer of 1954, Patrice Lumumba was granted immatriculation and could now be entered into the "Register of the Civilized." ${ }^{1}$ Like all those enjoying this legal status, from now on Lumumba no longer had to fear floggings, had equality with Europeans under penal law and was permitted to socialize and drink wine in European districts at night. In brief, he was a member of what colonial policy envisaged as the Congolese elite. But how were holders of this status selected and by whom? What were the key criteria? Who was granted this special legal status? And what advantages did the status reforms confer?

We may describe the practical implementation of these reforms as an attempt to translate the attributes of the "perfected black," as negotiated and propagated in the media, into bureaucratic test criteria. Ultimately, the selection procedure for the carte du mérite civique and immatriculation turned out to be a perfidious practice of colonial rule, with dual objectives. Despite the authorities' declared commitment to reforms, the goal was to uphold the social order while lending new legitimacy to the hegemony-stabilizing colonial distinction between European and African society.

It is important to reaffirm that, despite resistance from the European colonial milieu, the elite's demand for legal equality with Congo's European population managed to effect an initial shift of political direction. But the introduction of the carte du mérite civique in July 1948 was only a partial victory. As we will see later in more detail, the relevant decree merely promised several benefits for its holders, to be granted little by little, and the abolition, in part, of the indigénat. This did not, therefore, constitute full legal assimilation of the kind initially demanded by Congolese authors. The carte du mérite civique was no more than a transitional solution through which the architects of colonial policy wished to gain time in order to lay the ground for a more far-reaching reform of immatriculation. At the same time, therefore, Colonial Minister Wigny had instituted an ex-

1 Decree on immatriculation of 17 May 1952, AA/AI/4743/II/T/4.

Ә OpenAccess. (C 2021 Daniel Tödt, published by De Gruyter. (cc)BY Creative Commons Attribution 4.0 International License. https://doi.org/10.1515/9783110709308-007 
pert commission, headed by renowned colonial jurist Antoine Sohier. The commission was to come up with proposals to resolve the pressing issue of the "status of the civilized Congolese population." 2 This also ushered in the next round of controversy over the legal and cultural assimilation of the vernacular elite.

A good deal of time was to pass before the Sohier Commission put forward its suggested reform of immatriculation. Guided by the aspiration of creating a graduated legal system, one that had to reflect the differing developmental levels of the heterogenous group of évolués and serve as a gauge for the successive granting of rights, for two years the participating jurists discussed changes in specific areas of law. ${ }^{3}$ For whom, on what premises, should legal discrimination be eliminated in the fields of family, education and citizenship, property and residence? In addition to this hierarchy of legal subjects, based on differing levels of civilizational development, the Sohier Commission also proposed a status for those Congolese "who have fully acquired European civilization." 4 For this group of the "assimilated," Sohier envisaged nothing less than legal equality with the European population across the board. The foundation here was to be a reform of immatriculation, which previously granted Africans equality with Europeans only in matters of civil law. The limited target of this expanded form of immatriculation was a small group of priests and future university graduates.

This proposed reform too caused controversy, not least as it had to be passed by the Conseil de Gouvernement in Léopoldville, which had rejected the carte du mérite civique in 1947. This time around, the publicly proclaimed goal of legal equality for an assimilated elite triggered a yet more vehement reaction in the European settler milieu. It led to the amalgamation of the settlers' associations, which had been operating on a regional basis, to create a colony-wide umbrella body known as the Fédération des unions provinciales de colons au Congo et au Ruanda-Urundi (FEDACOL). ${ }^{5}$ In continuity with its predecessor organizations, which had emerged in the inter-war period, the FEDACOL championed a statebacked European settlement policy and demanded that Europeans' supremacy over the Congolese population be maintained through legal and economic priv-

2 Letter from Van Hove to colonial minister, 10 February 1948, AA/AI/4743//III/T/4.

3 On the following remarks, see Young, Politics, 79-87; Anstey, "Belgian Rule," 206; De Schrevel, Les forces politiques, 142-144.

4 A. Sohier, "Le problème des indigènes évolués et la commission du statut des congolaises civilisés,” Zä̈re 8, no. 3 (1949).

5 For a detailed account of FEDACOL, see Lemarchand, Political, 83-88; De Schrevel, Les forces politiques, 50-63. 
ileges. ${ }^{6}$ In the inter-war period, Belgian colonial policy had impeded the immigration of settlers, partly because the financially strong firms in the Congo, already struggling to recruit enough manpower, were eager to avoid the arrival of new competitors. After 1945, Brussels began to promote the settlement of Belgian farmers by providing them with financial aid. ${ }^{7}$ But this was no more than symbolic politics when set against the demands issuing from the settlement organizations in Katanga for settlers' political integration, to be achieved through the establishment of parliaments and a form of suffrage limited to Europeans, akin to the situation in the British dominions. Settlers in Katanga sometimes went so far as to claim autonomous status, not least because tax revenues from the industrial firms in their province made up almost half of the colony's budget. While the FEDACOL purported to act as the voice of all settlers, its leaders were from Katanga.

On the Conseil de Gouvernement, the FEDACOL had a high-profile representative in the shape of its president Oscar Defawe, who had been resident in Katanga since the 1920s, initially as an administrative official and then as a businessman. Defawe was also considered a war hero, having joined the Belgian resistance in the Second World War and been interned for a time by the Gestapo. ${ }^{8}$ During the session of summer 1950, Defawe presented himself as the "voice of a large number of colonizers and their children," who had "everything to lose" from the assimilation of an "immature people." "Defawe defended the status quo by pointing to the colonial wars raging in Indochina and Java, which he traced back to the emancipatory post-war reforms implemented by the other European colonial powers: "Do you believe, for instance, that France, Holland and Great Britain would pursue the same policy again if they could start over?," as Defawe asked the members of the Conseil de Gouvernement. He also lamented the limited political rights of the Belgian Congo's settlers. His reference to the Boers, of European descent, whose secessionist efforts in the resource-rich region of Transvaal around 1900 had initially been put down by the British empire but who had now proclaimed the independent Apartheid state of South Africa, was a clear threat from a prominent figure in the prosperous province of Katanga. "The assimila-

6 On the organization of settlers' interests since the 1930s, see Lemarchand, Political, 82-88. 7 B. Jewsiewicki, "Le Colonat agricole européen au Congo Belge, 1910-1960, problèmes politiques et économique,” Journal of African History 20 (1979): 565-566.

8 G. Derkinderen, “Oscar Defawe,” in Biographie Belge d'Outre-Mer, vol. 7-A, ed. Académie Royale des Sciences d'Outre-Mer (Brussels: Librairie Falk fils, 1973).

9 The quotations in this paragraph are from a speech by Oscar Defawe to the Conseil de Gouvernement, 20 July 1950, published in FEDACOL, L'opinion publique coloniale devant l'assimilation des indigènes (Brussels: mimeographed, 1951), 7-9. 
tion of an anomalous assemblage of so-called évolués," as Defawe concluded his combative speech, "would entail premature emancipation and the tyranny of a small minority."

That Sohier's outline project had been submitted to the Conseil de Gouvernement just a few days before it met, was used by other anti-reform members as a pretext for postponing the decision until the next year. But in light of the warnings given by some representatives of Congolese interests against any new disappointment for the vernacular elite, finally the Conseil de Gouvernement acceded to the governor general's request to pass the draft reform on to the conseils de province for debate in the meantime. Within just three months, their assessment was communicated to the Députation Permanente, instituted within the General Government in 1947, in order to provide the Colonial Ministry with a recommended course of action as soon as possible. ${ }^{10}$ Through this unprecedented procedure, Governor General Eugène Jungers was trying to retain the colonial government's control over assimilation policy and to expedite a decision before the next sitting of the Conseil de Gouvernement. Instead, he lost all control over such matters.

While the provincial councils discussed the Sohier Commission's proposal, opponents of the policy of assimilation from the European settlers' milieu readied themselves for action. Those constituting the "thin white line" ${ }^{11}$ feared above all the loss of their distinctiveness, the delegitimization of their supremacy within colonial ideology. For them, legal assimilation was merely the first step towards political self-determination for Congolese, which threatened to turn the European minority into a political minority as well. The lack of a political say was a major cause of concern for the 40,000 Belgians in the Congo, who lost their right to vote as temporary residents of the colony. ${ }^{12}$ In addition to technical impediments, the colonial state identified the high proportion of non-Belgian Europeans in the Congo as a reason for this denial of a core component of Belgian citizenship. After 1945, the potential to exercise a political influence was limited to the representatives of interest groups on the councils serving the various ad-

10 Sohier, "Le problème des indigènes," 142.

11 This is the term used by historian Anthony Kirk-Greene to describe the numerically small stratum of European administrators in the colony; Kirk-Greene, A., The Thin White Line: The Size of the Colonial Service in Africa (Oxford: Oxford University Press, 1980). It is equally apt for settler colonies with a larger European population. See C. Marx, "Siedlerkolonien in Afrika. Versuch einer Typologie," in Rassenmischehen - Mischlinge - Rassentrennung. Zur Politik der Rasse im deutschen Kolonialreich, ed. F. Becker (Stuttgart: Franz Steiner, 2004).

12 R. Lemarchand, "The Limits of Self-Determination: The Case of the Katanga Secession," American Political Science Review 56, no. 3 (1962): 407; Jewsiewicki, "Le Colonat.” 
ministrative levels. ${ }^{13}$ Hence, Brussels was worried not just about the loyalty of the vernacular elite, but also about the settlers' consent. One of the key goals of colonial policy was to stymie secessionist ambitions, especially in the economically important southern provinces, which were also the ones with the greatest number of European settlers. The Colonial Ministry looked on with concern as the white settlers in neighbouring Rhodesia, taking South Africa as their role model, mobilized for political independence under white leadership. ${ }^{14}$ In Angola too, bordering Congo in the southwest, the self-confidence of the Portuguese colonatos was growing; while they had no right to vote, after the Second World War, in contrast to Belgian policy, the state supported their settlement, so that by 1950 they had almost doubled in number, to just under 80,000. ${ }^{15}$ Belgian politicians with a focus on colonial policy feared for good reason that the region of Katanga was not only geographically nearer to the Rhodesian capital of Salisbury and Portuguese Luanda than to Léopoldville, but that it was also closer in ideological and political terms.

Against this background, it is hardly surprising that the granting of equality with Europeans to selected Africans, as envisaged in Sohier's immatriculation reform, sparked off an intense debate. European and Congolese spokesmen, segregated but keeping a close eye on one another, engaged in trench warfare in the media. In September 1950, the Union agricole du Kivu (UNAKI) warned of the "fatal consequences" 16 of assimilation. In a press release published the same time, the Union pour la Colonisation (UCOL), the regional settlers' association in Katanga, insisted on the differences between Europeans and Africans, which were not interpreted as biological, but as comparably insurmountable. According to this organization, the two groups were still divided by moral values that had evolved over the course of history and were culturally transmitted: "The Congolese [...] readily emulates the good example, but his ancestors have left him no spiritual or material legacy whatsoever that would allow him to play an active part in the modern world."17

13 See Lemarchand, Political, 75-76.

14 On the Rhodesian settlers and their struggle for independence, culminating in the proclamation of the Republic of Rhodesia in 1965, see J. L. Fisher, Pioniers, Settlers, Aliens, Exiles. The Decolonisation of White Identity in Zimbabwe (Canberra: ANU Press, 2010), 1-6.

15 Albertini, Dekolonisation, 596.

16 UNAKI communication of 20 September 1950, reprinted in FEDACOL, L'opinion publique, $21-23$.

17 UCOL Communiqué no. 245, 20 September 1950, reprinted in FEDACOL, L'opinion publique, 25. 
These groups directed their ire against Belgian politicians pursuing colonial policies while lacking awareness of local realities and allowing themselves to be driven by "UN alarmism." 18 In addition to the settlers, other influential voices from Katanga also spoke out against the Sohier reform. In a detailed statement on Sohier's proposal, the CEPSI research institute in Elisabethville, which specialized in indigenous policy issues, raised the question of why the colonial state was entering into such a conflictual debate on legal equality in the first place, given that the target group of assimilated Congolese, made up of priests and secondary school graduates, was so small. ${ }^{19}$ One day before the decision of the Députation Permanente on status reform, the cardinal of Katanga, Mgr. Hemptinne, stated his views in the conservative Essor du Congo. He referred to assimilation as "premature" and advocated a form of immatriculation extending only to equality under civil law, as the 74-year-old clergyman had himself called for in the interwar period as a leading member of the CPPI. ${ }^{20}$

While influential sections of the European milieu expressed their opposition in newspaper articles and press releases, it was not long before Congolese authors responded. The Voix du Congolais was still the key media forum where authors could aid the supporters of status reform by arguing that their developmental level made legal equality indispensable. One of the leading exponents of legal assimilation was Antoine Omari, originally from the eastern province of Kivu, who was now a bookkeeper at the colony's most important construction firm, Synkin, in Léopoldville and a leading member of elite groupings such as the aforementioned Cercle d'Études et d'Agréments and the Union des Intérêts Sociaux Congolais (UNISCO), a Congolese advocacy group close to the ADAPES. Omari legitimized his demands based on the civilizing mission of Belgian colonialism and invoked King Leopold II: "The time has surely come, [...] to open the door to assimilation, terminus ad quem of the humanitarian goals our ruler Léopold II has assigned to us."21

Compared with the flood of articles published in 1945 at the start of the debate on évolué status, initially the authors writing for the Voix du Congolais commented on the work of the Sohier Commission rarely and with great circumspec-

18 P. Dechamps, "Quos vult perdere Jupiter dementat ... Un joli travail," Kasai, 14 October 1950, reprinted in FEDACOL, L'opinion publique, 47-49, 48.

19 CEPSI statement on immatriculation, 28 September 1950, in FEDACOL, L'opinion publique, $28-32$.

20 J. F. Hemptinne, "Remarque concernant les projets de Décret sur l'immatriculation," Essor du Congo, 25 November 1950, reprinted in FEDACOL, L'opinion publique, 52-56.

21 A. Omari, “A propos de la Carte du mérite Civique,” Voix du Congolais no. 51 (June 1950). 
tion. ${ }^{22}$ Subsequent to the resistance on the Conseil de Gouvernement, however, their reportage regained a combative tone. In the October 1950 issue, editor-inchief Antoine-Roger Bolamba argued that while one could never make "a black into a white," it was beyond doubt that "henceforth, some Belgian Africans are already comparable with their custodians." ${ }^{23}$ From this point forward, Congolese authors reminded the opponents of assimilation of the noble goals of the Belgian colonial project. In the same issue, the editors published a selection of articles composed by correspondents in reaction to the publicly aired resistance within the settlers' milieu. In addition to contributions from the abovementioned Omari, these included an article by Jean-Pierre Dericoyard, another member of the Cercle d'Études et d'Agréments. Following a career as a highlevel clerk in the private sector, Dericoyard had built up a lucrative furniture business in Léopoldville and was one of the few évolués to succeed as a merchant. ${ }^{24}$ He assailed the critics of immatriculation as "NEGROPHOBES." 25 Dericoyard argued deftly against the idea of an insurmountable gulf between the cultural and moral beliefs of Europeans and Africans as anchored by UCOL in the two groups' developmental history. If the spread of civilization in Europe as initiated by the Romans had taken 2,000 years, then this was solely due to the "slow development of this era." The colonized countries, by contrast, who were now in contact with the "previously civilized," 26 would acquire the benefits of civilization far more rapidly. While the opponents of assimilation sought to delay reforms, then, representatives of the Congolese elite tried to accelerate the pace of change.

In light of the increasingly polemical tone in colonial newspapers with a European readership, culminating in the headline "The assimilated and the cannibals," Antoine-Roger Bolamba called on European authors to embrace reason and common sense. ${ }^{27}$ With a view to the disparaging remarks made in the media, Bolamba wrote that "we wonder bitterly why some Europeans insist on refusing to develop." For a "sincere, cordial and fraternal cooperation between

22 N. D. L. R., Voix du Congolais no. 40, July 1949, 267. For a similar wait-and-see approach, see n.n., “A propos du statut de la population congolaise civilisé,” Voix du Congolais no. 41 (August 1949): 297-299.

23 A.-R. Bolamba, “Assimilation,” Voix du Congolais no. 55 (October 1950): 573.

24 Artigue, Qui sont, 63.

25 J.-P. Dericoyard, “A propos du problème de l'assimilation des congolais," Voix du Congolais no. 55 (October 1950).

26 Ibid., 577.

27 A.-R. Bolamba, “La presse européenne et les Congolais," Voix du Congolais no. 57 (December 1950). 
the two races," it was not just Congolese that had to work on themselves but Europeans too. ${ }^{28}$ The Voix $d u$ Congolais portrayed the European settlers as the perpetual men of yesterday, who had fallen behind the times with their critique of reform. The self-confident tone of these articles penned by the distinguished representatives of the vernacular elite in Léopoldville, who were close to the progressive forces within the colonial administration, was perceived as overblown by authors associated with the settlers' lobby. The newspaper was supposed to be controlled by the colonial government, as one spokesman for the settlers of Katanga remarked indignantly in the Kasai daily newspaper. ${ }^{29}$

Once again, it is important to bear in mind that the Congolese intervention in the debate on assimilation was the work of a numerically small educated elite. At this point in time, the number of permanent and freelance contributors to the Voix $d u$ Congolais was just under two hundred, while its monthly print run was less than 5,000 copies. But as representatives of the évolués, the authors spoke on behalf of the just under 60,000 Congolese who had by now attended secondary school and were doing non-manual work. ${ }^{30}$ These authors erroneously assumed, however, that the debate was concerned with their own legal equality. For the Sohier plan for immatriculation was geared exclusively towards priests and the future graduates of universities. While the writing elite staked out their claim to immatriculation by highlighting their development, their European opponents furiously denied these "pen-pushers"31 this right.

The assessments made by the provincial councils and the Députation Permanente ultimately revealed the strong influence of the settlers' lobby, whose objections found reflection in their statements. Not only did the settlers' representatives dominate in the provincial councils, but the particularly polemical Oscar Defawe also sat on the Députation Permanente, composed of three colonial officials and six lobbyists. While both forums welcomed the évolués' efforts to achieve cultural assimilation, the legal equality demanded in the Sohier Commission's draft reform met with categorical rejection. ${ }^{32}$ In December 1950, the

28 Bolamba, “Assimilation," 574.

29 P. Dechamps, "Quos vult perdere Jupiter dementat ... Un joli travail,” Kasai, 14 October 1950, reprinted in FEDACOL, L'opinion publique, 48.

30 On the figures, see Van Wing, "La formation," 9; Chambre des représentants, Rapport sur l'administration de la colonie du Congo Belge pendant l'année 1951 présenté aux chambres législatives (Brussels: Ministere des affaires africaines, 1952).

31 P. Dechamps, “Toujours l'assimilation ... Il faut être juste," Kasai, 8 September 1951, reprinted in FEDACOL, L'opinion publique, 129-132, 129.

32 Statements appeared in Courrier d'Afrique (28 Novermber 1950). See Anstey, "Belgian Rule," 211; Young, Politics, 81-82. 
Députation Permanente merely agreed to the principle of immatriculation, while limiting the associated benefits in terms of legal equality to civil law. Further, the individual rights of a yet to be defined group of assimilated Congolese were to be extended with the help of decrees. The circle of potential candidates for immatriculation was also expanded. ${ }^{33}$ This watered-down reform proposal from the Députation Permanente was then passed to the Colonial Ministry in Brussels, where it was to be reviewed by the Conseil Colonial.

Meanwhile, the speech given by Governor General Eugène Jungers at the opening of the Conseil de Gouvernement in July 1951 caused a new stir. In his remarks on elite-making policy, he recapitulated the recommendations of the Députation Permanente on the Sohier reform, but continued to hold out the prospect of legal equality for the assimilated. ${ }^{34}$ Jungers thus left open what the Colonial Ministry's decision on this issue would ultimately be. He saw the task of future policy as the elimination of discrimination against Congolese and appealed for the European population to keep an open mind. The anti-reform settlers' milieu viewed his dictum that "the hand extended too late risks being declined" as a disturbing declaration of intent.

Jean Sepulchre, editor of the Essor du Congo in Elisabethville, which was close to the settlers, ranted that "the Belgian hand has pulled the indigenous masses up out of their barbarism, leading them to material improvements and their elite to moral and intellectual progress." ${ }^{35}$ He accused the governor general "of breaking, in an oddly festive way, with the traditional method of the slow but sure development of our charges." 36 The lobbying of those opposed to reform in Katanga now expanded to Brussels, where the Colonial Ministry had the power of decision. In a memorandum, the members of the Katanga Chamber of Industry and Commerce personally informed the colonial minister that the assimilation advocated by the governor general would be impossible to implement. ${ }^{37}$ FEDACOL, which now had a lobbying office in Brussels, sent the colonial minister a press review featuring newspaper articles from the previous one-and-a-half years, so that the "colonial public's view of assimilation” would be considered

33 Ibid.; De Schrevel, Les forces politiques, 146.

34 "Texte du discours prononcé par M. Gouverneur Général Jungers lors de l'ouverture de la Session de 1951 du Conseil de Gouvernement," Voix du Congolais no. 66 (September 1951): 477-502.

35 J. Sepulchre, "A la croisée des chemins," Essor du Congo (8 August 1951), reprinted in FEDACOL, L'opinion publique, 96-100, here 99.

36 J. Sepulchre, “Le ministre des colonies parmi nous," Essor du Congo (18 August 1951), reprinted in FEDACOL, L'opinion publique, 116.

37 De Schrevel, Les forces politiques, 28. 
when the decisions were made. In the foreword, FEDACOL president Albert Maus, a plantation owner from the Belgian mandate of Urundi, warned against giving "a bunch of individuals of an inferior civilizational, intellectual and moral state of development" equal status with Europeans, who were "very aware of the superiority of their Western civilization." He accused those politicians concerned with colonial policy of caving in to "a few thousand impatient évolués," who "are convinced that assimilation is their fate." Maus warned against "the hazardous policy of a far-off and physically shielded legislature, inspired by a combination of ideals and ignorance of the realities." 38

In March 1952, after several rounds of consultation on the Sohier reform, the Conseil Colonial backed the conservative compromise proposal put forward by the Députation Permamente. The advisory body recommended to the Colonial Ministry, first, a reformed version of immatriculation, which guaranteed equality under civil law to selected Congolese. Second, together with holders of the carte du mérite civique, the immatriculated were to be placed on an equal footing with Europeans under penal law. ${ }^{39}$ But the Conseil Colonial rejected legal assimilation across the board. The goal of colonialism had never been to turn Africans into Europeans, as the minutes of its proceedings baldly stated. ${ }^{40}$ The immatriculation subsequently introduced by the colonial minister in May 1952 was a typically Belgian balancing of interests, a compromise solution that yielded to pressure from the settler milieu but could still present the vernacular elite with a result.

In the Voix du Congolais, once again the Congolese authors toed the line and embraced the political compromise. The departure from legal equality went unmentioned in the commentaries, with Antoine-Roger Bolamba loyally welcoming the "flexible approach of immatriculation." 41 Omari, shortly before a leading advocate of complete assimilation, went so far as to call the Conseil Colonial's decision "excellent news" and rejoiced that "assimilation is assured." 42 As with the carte du mérite civique, in view of this meagre reform of immatriculation the authors writing for the Voix $d u$ Congolais did the only thing they could do in the General Government's press organ: they kept quiet about what they had demanded and welcomed the watered-down but still hard-won reform as an irrev-

38 A. Maus, “Avant-propos,” reprinted in FEDACOL, L'opinion publique, 2-5, 5.

39 Report by the Conseil Colonial, reprinted in Courrier d'Afrique (26 March 1952).

40 Rapport du Conseil Colonial (Brussels: 1952), 1175-1179, quoted in De Schrevel, Les forces politiques, 147.

41 A.-R. Bolamba, "La députation permanente et l'assimilation des autochtones," Voix du Congolais no. 60 (March 1951): 116.

42 A. Omari, “Une excellente nouvelle,” Voix du Congolais no. 74 (May 1952): 257. 
ocable political decision made in Brussels. They remained évolués loyal to the party line.

When Antoine Sohier had taken over as head of the status commission, he saw the évolués problem as rooted in the fact that they had answered the call to civilize but now found themselves facing a "closed door." 43 Sohier perceived a solution to this in his proposal for a form of immatriculation that guaranteed equal rights: "The door is open, now it is down to you to walk through it,"44 he wrote in defence of his assimilation policy. By rejecting Sohier's reform proposal, however, the Colonial Ministry asked the Congolese elite, in the waiting room of colonial development, for a little more patience.

In light of the intense debates within the colonial public sphere, the question that arises is what legal and material benefits the carte du mérte civique and immatriculation actually bestowed. Through this two-tier status reform, the Colonial Ministry had signed up to the principle that the benefits accruing to holders of the carte $d u$ mérite civique and the immatriculated would come into effect incrementally. When the carte du mérite civique was initially introduced as a transitional solution in 1948, strictly speaking this did not amount to a legal status. Instead, in article xiv the relevant decree recognized cardholders' legal distinction vis-à-vis African society in principle, but failed to define it more precisely. ${ }^{45}$ Instead, for this "category of natives" 46 benefits were to be realized within the framework of existing legislation and regulatory practice. Rather than guaranteeing cardholders' legal equality with Europeans, at best the decree was a promise made by colonial policy to gradually remove them from the indigénat and grant them certain privileges. This was no longer a matter of rights but of fewer prohibitions and less severe punishments. The assumption in the Colonial Ministry was that even more important than the benefits was the recognition cardholders would gain from Congolese and European society. ${ }^{47}$

On closer inspection, the benefits granted by the carte du mérite civique were modest in the first few years. In the period between September 1948 and the re-

43 Sohier, "Le problème des indigènes," 844.

44 A. Sohier, "La politique d'intégration,” Zaïre 11, no. 5 (1951): 905-906.

45 Ordonnance $\mathrm{N}^{\circ} 21 / 258$ AIMO du 12 Juillet 1948 créant une carte du mérite civique, reprinted in Voix du Congolais no. 30 (September 1948): 363; Normes pour obtenir la carte du mérite civique, $\mathrm{AA} / \mathrm{AI} / 4743 / \mathrm{II} / \mathrm{T} / 4$.

46 Ibid.

47 This also emerges from correspondence between political decision-makers; letter from Van Hove to the colonial minister, 22 July 1949, AA/AI/4743/II/T/4. The views of the Colonial Ministry were thus in accord with those of Antoine Sohier, who headed the commission for the reform of immatriculation; letter from Sohier to the colonial minister, 27 June 1949, AA/AI/4743/II/T/4. 
form of immatriculation in mid-1952, the colonial government issued several regulations. Henceforth, cardholders were spared punishment through flogging, were allowed to exploit mineral resources and in case of legal disputes could apply to a European judge. In addition, they would no longer be subject to the night-time curfew in the African quarters. ${ }^{48}$ The privilege of being exempt from flogging, however, lasted for less than three years, as this controversial punishment was then universally prohibited. ${ }^{49}$

Soon after the introduction of the carte du mérite civique unrest began to spread among the évolués. As the official voice of the vernacular elite and tireless advocate for status reform, the Voix du Congolais felt obliged to give expression to the dissatisfaction felt at the card's thin pickings: "What good is the document to us?,"50 asked editor-in-chief Antoine-Roger Bolamba in July 1951. Measured against the great hopes fuelled by the newspaper over the years, the benefits of the carte du mérite civique fell short of expectations.

From mid-1952 on, criticisms of the long-discussed évolué status continued to mount. For the reform of immatriculation was also a disappointment: it too failed to introduce legal equality with Europeans and was limited to assimilation under civil law. Nonetheless, the associated decree declared grandiloquently that the "realm of our European civil rights"51 had now been extended to the immatriculated. ${ }^{52}$ What distinguished immatriculation from the carte du mérite civique was that the legal status it provided applied to the applicant's entire family. Furthermore, in case of wrongdoing one could not be stripped of immatriculation, which thus offered greater reliability than the carte du mérite civique. ${ }^{53}$ At the end of the day, resistance from the settlers' milieu and the controversy over the scope of the status had dissuaded the Colonial Ministry from pursuing comprehensive legal assimilation. To avoid losing room for manoeuvre, when it came to immatriculation the Colonial Ministry opted for the piecemeal extension of privileges through decrees, as already practised in the case of the carte du mérite civique.

On the day immatriculation was introduced, for example, the authorities enacted equality with Europeans under penal law. From now on, trials of the immatriculated were no longer to be held before the police court, but before the

48 On the benefits enjoyed by cardholders, see Carte du mérite civique, AA/AI/4743/T/4. 49 Ibid.

50 A.-R. Bolamba, “A quoi nous sert ce document?,” Voix du Congolais no. 64 (July 1951).

51 Immatriculés et Porteurs de la Carte du mérite civique, AA/AI/4743/T/4.

52 Le décret du 17 mai modifiant les dispositions du code civil sur l'immatriculation des congolais, reprinted in Croix du Congo (13 July 1952).

53 Mutamba-Makombo, Du Congo belge, 74. 
courts of first instance; they could expect the same conditions of detention and rehabilitation as Europeans. The immatriculated, however, did not obtain these privileges exclusively, but shared them with the holders of the carte du mérite civique, for whom penal harmonization came into force simultaneously. ${ }^{54} \mathrm{Com}$ mentaries on these initial privileges focussed not so much on the satisfaction felt at the prospect of an independent court process as on the financial disbenefits accruing to those involved, as they would no longer enjoy reduced legal costs. ${ }^{55}$ Furthermore, many wondered what palpable benefits might be associated with equality under penal law, given that those granted it had to produce a spotless certificate of good conduct anyway. ${ }^{56}$ In Brussels, scornful remarks from the Belgian Congo reached the ears of the colonial minister to the effect that évolué status was attractive only to future "offenders." 57

Over the next few years, several new decrees were issued affecting the holders of the carte du mérite civique and the immatriculated. From March 1954 on, the latter were permitted to move about freely in the European residential zones. ${ }^{58}$ When it came to the right of possession, the colonial government also granted the immatriculated full legal capacity. That this was important to those who dealt in property is shown by one applicant for immatriculation who saw this as the only means of attaining full contractual capability. ${ }^{59}$ Most of these decrees, however, applied equally to the immatriculated and to holders of the carte du mérite civique. ${ }^{60}$ The restrictive laws on alcohol consumption that created separate realms of consumption for Europeans and Congolese were rescinded for both these legal categories. They were now permitted to drink wine and hard liquor. ${ }^{61}$ They could attend public film screenings without exception, which was relevant in the sense that all other Africans were only permitted to watch films authorized by a board of censors.

But this was all there was to the legislative measures implemented by the colonial government for the immatriculated and holders of the carte du mérite

\footnotetext{
54 Immatriculés et Porteurs de la Carte du mérite civique, AA/AI/4743/T/4.

55 Ibid.

56 Report by CEDIC, 23 May 1953, quoted in De Schrevel, Les forces politiques, 145.

57 Letter from the governor general to the governor of Équateur province, 25 April 1953, AA/GG/ 11096.

58 Immatriculés et Porteurs de la Carte du mérite civique, AA/AI/4743/T/4.

59 "Jurisprudence, Immatriculation. Conditions," Journal des tribunaux d'outre-mer 41 (15 November 1953): 164.

60 A schematic but incomplete account of what the carte du mérite civique and immatriculation had in common and where they differed is provided by Mutamba-Makombo, Du Congo belge, 74. 61 Though this applied only in the provinces of Léopoldville, Katanga and Kasai; Immatriculés et Porteurs de la Carte du mérite civique, AA/AI/4743/T/4.
} 
civique. In the cold light of day, the benefits accruing to the elite entailed the selective dismantling of forms of legal discrimination that remained valid for the rest of the Congolese population.

The critique emanating from the évolué milieu that elite status did not entail economic assimilation was noted within the upper echelons of the colonial administration. ${ }^{62}$ Disappointed hopes of financial improvement caused elite status to lose some of its appeal. The head of one selection committee for the carte $d u$ mérite civique thus reported to the provincial governor the "lack of enthusiasm prevailing among this section of the population." The roots of this disappointment, he explained, lay in the fact that this status entailed no material benefits and that the évoluants attached less value to the "moral and civic virtues" than to "external signs of prosperity." 63 A survey carried out by the awarding committee in Kivu painted a similar picture of prevailing attitudes: "It is not worth acquiring the card," ${ }^{64}$ was one of the views expressed. That the reform of immatriculation had also backed away from an article unique, which would have meant equal pay for the immatriculated and Europeans, ${ }^{65}$ inevitably caused dissatisfaction among évolués. For the world of work continued to treat Europeans and Congolese differently: the former were employed within the framework of a contrat d'emploi, which still provided for greater income, even for the lowest salary bracket, than the best paid contrat de travail, which applied to the latter. ${ }^{66}$ The colonial administration's annual report for 1955 noted that the lack of "material benefits" had prompted many Congolese to refrain from applying for immatriculation. ${ }^{67}$ A large number of them thus made do with the carte du mérite civique.

62 Letter from the governor general to the governor of Équateur province, 25 April 1953, AA/GG/ 11096.

63 All quotations from letter from the district commissioner of Lac Léopold II to the governor of Léopoldville province, 13 February 1950, AA/GG/15726.

64 Minutes of the district committee in Kivu on the issuing of the carte du mérite civique, 3 February 1949, AA/GG/18708. The same document cites another criticism of equality under civil law, namely that divorces were less complicated under traditional law.

65 See Anstey, "Belgian Rule," 209.

66 It has been claimed that the head of the Immatriculation Commission, Antoine Sohier, himself backed away from the demand for equality between Europeans and Africans in this regard. He believed he was acting in the interests of the immatriculated. On the premise of equal pay, he concluded, they would have stood no chance against European candidates when applying for jobs; see ibid.

67 Chambre des représentants, Rapport sur l'administration de la colonie du Congo Belge pendant l'année 1955 présenté aux chambres législatives (Brussels: Ministere des affaires africaines, 1956), 100. 
Despite offering similar privileges, it was easier to acquire and the application process was less expensive. ${ }^{68}$

Many representatives of the African elite were particularly unhappy about the financial cost of a successful application for évolué status and the time and effort they had to put into it, all of which they saw as out of all proportion to its true utility. "There are many duties to perform but it provides no great benefits," ${ }^{69}$ wrote one author with a view to the strict selection procedure.

\section{Civility, selection committees and delayed inter-imperial transfers}

In the colonial public sphere, however, the issue of the utility of the status reforms took up less space than that of the admission criteria. How were interested Congolese meant to attain this status? Who was to be granted the so-called "certificate of civilization"70 and according to which criteria?

Let us turn first to the selection procedure for the carte du mérite civique, which later served as a template for the granting of immatriculation. According to the decree on the card of 12 July 1948, all African residents of the Belgian Congo and Ruanda-Urundi, a UN trusteeship under Belgian administration, could submit their oral or written application to the relevant territorial official. ${ }^{71}$ The basic conditions included a monogamous lifestyle, a minimum age of twenty-one and a clean criminal record over the previous five years. The illiterate had to provide employment references, while women had to show proof of attendance at a foyer social. There were also subjective criteria, which played a crucial role in the selection procedure. The candidates had to "demonstrate good behaviour and habits indicative of a sincere desire to attain a higher level of civilization."72

68 Letter from the governor general to the governor of Équateur province, 25 April 1953, AA/GG/ 11096.

69 Minutes of the district committee in Kivu on the issuing of the carte du mérite civique, 3 February 1949 , AA/GG/18708.

70 This term was used in an internal document produced by the Colonial Ministry; Normes pour obtenir la carte du mérite civique, $\mathrm{AA} / \mathrm{AI} / 4743 / \mathrm{II} / \mathrm{T} / 4$.

71 African residents from neighbouring colonies could apply for a carte du mérite civique if they had lived in the Belgian Congo for at least five years. But the largest group, namely the Coastmen, who were born in Nigeria and the Gold Coast and worked for British firms, were barred from applying. Ibid.

72 Ibid. 
Furthermore, the recommendations made by the Congrès National Colonial had already featured pleas for "strict selection." ${ }^{73}$ In the Voix du Congolais in particular, where month after month authors exchanged views on which behaviours made a "genuine" évolué, calls were soon being made for strict screening. As we have seen, the mockery of the évolués in the European newspapers as polygamous, overbearing and overly attached to alcohol had gone hand in hand with Congolese authors' critique of allegedly unworthy representatives of their group: it was always somebody else who was assailed for being a snob. ${ }^{74}$ In an editorial, for example, Antoine-Roger Bolamba wrote that the carte du mérite civique "is meant to separate the genuine from the false évolués." 75

The selection procedure to determine status, however, was by no means special to the Belgian Congo. In fact, Belgian elite-making policy took inspiration from the naturalization procedures in the French colonies. As mentioned earlier, the project to introduce an évolué status initiated in the Belgian Congo in 1944 had drawn on the statut des notables évolués, enacted in 1941 in neighbouring Brazzaville by Governor General Félix Éboué for the French colony of AEF. The statut des notables évolués promised the new social category of the African elite an intermediate position between citoyen and sujet français, which, among other things, entailed individual release from the indigénat. Applicants had to satisfy the local colonial administration that they were of "impeccable respectability" and "exceed the average level of the natives."

With this selection process, Governor General Éboué was taking his lead from the conditions the inhabitants of other parts of the French empire typically had to fulfil in order to attain French citizenship. ${ }^{77}$ Since the 1930s, the French colonial administration in Indochina, for example, had carried out selection interviews on naturalization. ${ }^{78}$ There, applicants were mostly so-called métis, the offspring of Asian and French parents who had grown up in Europe or in the European colonial milieu. They had to prove to French colonial officials that they had internalized "French civilization," with questions such as the following serving as the basis for evaluation: "Is he characterized by French courtesy? Does he

73 Piron, "Le problème," 15.

74 See for example A. Omari, "L'assimilation des Congolais," Voix du Congolais no. 55 (October 1950).

75 Bolamba, "Carte du mérite," 361.

76 Governor General Félix Éboué to governors and territorial administrators of AEF, 10 June 1943, CAOM/GG/AEF/5D206.

77 See Saada, “Entre 'assimilation' et 'décivilisation,” 33.

78 Ibid., 33-34. 
play French music?"79 These tests were the hallmarks of a French colonial ideology according to which the colonized had to acquire the European way of life through imitation while setting aside their culture of origin. ${ }^{80}$

In AEF, applicants for the statut des notables évolués had to be of legal age, to be able to read and write, to have served in the army, to be in gainful employment and to have a clean criminal record. Furthermore, they had to "be honourable, of excellent moral character and competent to participate actively in matters of administration and civil society." 81 The colonial officials on the spot decided which applications to approve after examining the candidates in detail. The governor of Oubangi-Chari, a region of AEF, provided the colonial officials with hints on how to assess whether applicants were suited to a role in disseminating French civilization as shining examples:

I request that you inspect their intimate sphere unnoticed through spot checks. A given applicant, for example, has mastered spelling and has fairly good syntax; he is always respectably dressed when he leaves the house, in shoes and a tie; he gets around on a bicycle, plays accordion and occasionally enjoys a bottle of beer. Take yourself along to his abode without warning; should you discover that there, although the head of the family has adequate financial means, people are eating the same cassava porridge as all the other labourers and eating with their fingers from old clay pots [...], you can conclude without hesitation that despite everything the applicant is not yet developed. ${ }^{82}$

The available sources do not reveal to what extent the French and Belgian colonial administrations exchanged information on their appointment policies. The proximity of the administrative headquarters in Léopoldville and Brazzaville may have facilitated informal meetings between colonial officials. What is certain is that from 1947 on, the Belgian General Government initiated several conférences interafricaines en matière d'éducation indigène in Léopoldville that brought together officials from British, French and Belgian colonies. Tellingly, the Belgian side was represented by the patron of the Voix du Congolais, Jean-Paul Quix; in the reform debate after 1945, he championed a blueprint for an évolué status that was astonishingly similar to that in the neighbouring colony of $\mathrm{AEF}^{83}$ The fact that from 1945 on, the Voix du Congolais and correspondence between the polit-

79 Dossiers de naturalisation produced in Indochina in the 1930s, quoted in ibid.

80 Ibid, 32-37.

81 Conditions Requises, Notable Évolués, n.d., CAOM/GG/AEF/5D206.

82 Letter from Governor Oubangi-Charis H. Sautot to the chefs de département et subdivision du territoire, 13 July 1943, CAOM/GG/AEF/5D206.

83 Report on the conférence Anglo-Franco-Belge sur l'éducation dans les territoires d'outre-mer, 10 - 14 June 1947, CAOM/GG/AEF/5D251. 
ical masterminds of elite status in the Belgian Congo repeatedly made explicit reference to the elite-making policy being pursued by Governor General Éboué in AEF shows that key actors in the Belgian colony were taking a good deal of interest in the neighbours.

We should not forget, however, that progressive forces in French colonial policy already regarded Éboués elite appointment policy as outdated at the time of its introduction. This is illustrated by the citizenship introduced in 1946 for all inhabitants of the Union Française, which rendered the benefits of the statut des notables évolués, only just enacted, redundant. ${ }^{84}$ The carte du mérite civique, then, involved an inter-imperial transfer that was more apparent than real. Its introduction in 1948 was an anachronism when compared with the other side of the Congo river. While French colonial policy had just broken away from the idea that legal equality between Europeans and Africans must be tied to cultural equality, ${ }^{85}$ this nexus survived in the practice of selecting the vernacular elite in the Belgian Congo.

In contrast to the AEF, it was not just a colonial official who was responsible for the selection procedure for the carte du mérite civique, but a multi-member committee, which met at the district administrative level and was officially appointed by the provincial governor. The decree of 12 July 1948 also specified the makeup of the committees, which consisted of four individuals, including a public prosecutor, a colonial official from the AIMO or the territorial administration and two bearers of the carte du mérite civique. ${ }^{86}$

While the presence of the European representatives on the committees comes as no surprise, the involvement of holders of the carte du mérite civique, which the committees were established to issue, seems odd. One of their first official acts was in fact to grant the card to their future Congolese members. As a rule, the district commissioner put forward a suitable candidate. ${ }^{87}$ This appoint-

84 Interestingly, the colonial administration in AEF examined the question of how one might retain privileges for bearers of the statut des notables évolués. The administration apparently feared that levelling off status-holders' hard-won distinction might lead to discontent among the African elite; letter from the governor of Gabon to the General Governor of AEF, 6 December 1946, CAMO/GG/AEF/5D251.

85 See Cooper, Citizenship; F. Cooper, "Reconstructing Empire in British and French Africa," Past \& Present 210, no. 6 (2011): $200-204$.

86 Ordonnance $\mathrm{N}^{\circ} 21 / 258$ AIMO du 12 Juillet 1948 créant une carte du mérite civique, reprinted in Voix du Congolais no. 30, September 1948, 363; Normes pour obtenir la carte du mérite civique, $\mathrm{AA} / \mathrm{AI} / 4743 / \mathrm{II} / \mathrm{T} / 4$.

87 Letter from the governor of Léopoldville province to the district commissioners of 16 October 1948. AA/GG/15726. 
ment practice did not go unopposed. Given that these committee members received the card without first being assessed for their suitability, in the Voix $d u$ Congolais Antoine-Marie Mobé, the former seminarian now employed in the administrative service, called the selection procedure itself into question: "We ask ourselves what the rationale for this process might be, for if this favour can be done for a small number of individuals, why can it not be made a general practice?"88 This criticism, however, was dismissed by the editors with reference to the good judgment of the European committee members. ${ }^{89}$

The selection of the Congolese members also raised the question of whether they were neutral enough to make objective decisions about the applications; the possible bias of European members, by contrast, was not discussed. In Léopoldville, for example, a European committee member, a social worker in the local foyer social, proposed increasing the number of Congolese members to four, in order to do justice to the internal divisions among évolués in the capital. What she had in mind here was chiefly the tensions between the members of the two alumni associations ADAPES and ASSANEF..$^{90}$

The need to appoint Congolese representatives delayed the start of the committees' real work. In the district of Lac Léopold II, for example, the local committee's final composition was only definitively settled one year after the introduction of the carte du mérite civique. Initially, the district commissioner had been dissatisfied with the territorial officials' suggestions. He categorized the candidates as "commonplace" and emphasized the importance of the criteria of "morality" and "loyalty." 91 When a selection had finally been made, one of the designated African members died, and the selection procedure started again from scratch. ${ }^{92}$

But in addition to appointing African committee members, there was still a need for clarification on substantive issues. The committees were exercised by the question of how to operationalize the selection criterion stipulated in the third paragraph of the sixth article of the decree. How could the "applicant's sin-

88 A.-M. Mobé, “A qui faut-il octroyer la carte du Mérite Civique,” Voix du Congolais no. 46, January $1950,16$.

89 "Note de la redaction," Voix du Congolais no. 46 (January 1950): 21.

90 Letter from A. Louwers, employee of the foyer social of Léopoldville to the district commissioner, 10 November 1948, AA/GG/19669. The district commissioner supported this proposal in a letter to the governor of Léopoldville province of 17 November 1948; see ibid.

91 Letter from R. Tonnoir, district commissioner of Lac Léopold II, to the territorial administrator of Inongo, 9 March 1949, AA/GG/15726.

92 Letter from the territorial administrator of Inongo to the district commissioner of Lac Léopold II, 23 May 1949, AA/GG/15726. 
cere desire" to "attain a higher level of civilization" be measured?93 Because applicants' civility determined the allocation of the cards, the committees were responsible for developing binding criteria that could be assessed through a bureaucratic selection procedure.

The committee in the administrative district of Kivu, an area dominated by a plantation economy, whose settlers' spokesmen had protested against the policy of assimilation, developed a detailed questionnaire that guided its assessment of applications. Is the applicant active in an association, and if so, does he pay his membership fees? Does he write for the African press? What does he do in his free time? Does he go to the library? What kind of music does he listen to at home? Does he use most of his salary on his household? Does his wife attend the foyer social? Were his offspring delivered at a hospital? What do his children's teachers have to say about them? Is the house well-maintained? Do the furniture and household utensils match the applicant's financial means? Has he attracted attention for immoral conduct, such as drunkenness, debts, magic or adultery ${ }^{94}$ In brief, the committees sought to expose every nook and cranny of applicants' lives to searing scrutiny.

The selection committees were not only required to clarify the vague criteria for the carte du mérite civique, but also to demonstrate a rigorous approach to issuing them. In a letter sent to the colonial minister during his work on the reform of immatriculation, jurist Antoine Sohier thus called for a strict screening of the first holders of the carte du mérite civique. In view of the resentment felt by Europeans in the colony, he contended, it was crucial to ensure that initially the card be awarded only to a "small number of carefully selected natives [...] of not only factual but incontestable merit." ${ }^{95}$ Representatives of the Colonial Ministry endorsed this view because they believed only a strict awarding practice could counteract the "shabby but unfortunately destructive criticisms made by the European population, which is generally hostile to the évolués." 96 As these officials saw it, the success of the project of promoting greater recognition for the évolués among the European residents of the colony through status reform depended on the quality of the cardholders: "To provide these Europeans with legitimate reasons to complain and play up isolated cases of rashly awarded benefits would do tremendous damage to our cause."97

93 Normes pour obtenir la carte de mérite civique, AA/AI/4743/II/T/4.

94 Minutes of the district committee of Kivu on the issuing of the carte du mérite civique, 3 February $1949, \mathrm{AA} / \mathrm{GG} / 18708$.

95 Letter from Antoine Sohier to the colonial minister, 27 June 1949, AA/AI/4743/III/T/4.

96 Letter from Van Hove to the colonial minister, 22 July 1949, AA/AI/II/T/4.

97 Ibid. 
In order to prevent a permissive approach to allocation, Governor General Eugène Jungers had initially dispatched a limited number of cartes du mérite civique to the relevant offices and declared this sufficient. ${ }^{98}$ Not long afterwards, however, he clarified that nonetheless all worthy candidates must be rewarded. ${ }^{99}$ The governor general declined a request from the provincial governor in Elisabethville, who had requested a further 150 cards less than two years after their introduction. ${ }^{100}$ The idea was to maintain a particularly rigorous approach to selection in those places in which European settlers were most critical of assimilation policy.

Yet even the authors writing for the Voix du Congolais advocated strict selection. The criticisms and contempt emanating from the European colonial milieu remained an important topic following the introduction of the carte du mérite civique. The reports in the newspaper, however, convey the impression that these authors' vehement calls for recognition of their developmental accomplishments in the European milieu had had the opposite effect. The disparagement of the évolués prompted even Etienne Ngandu, the leading author of the 1944 memorandum, to doubt whether the term was still an apt means of self-description: "In both word and deed, the white man has turned the word 'évolué' into a synonym for good-for-nothing and riff-raff. [...] Who still wishes to bear this name?"101

In response to a polemical article in the Revue congolaise illustrée, the press organ of the Association of Belgian Colonial Veterans published in Brussels, the Voix du Congolais announced that it would no longer be referring to évolués, an "abominable word"102 that lumped together a heterogenous group.

In the light of the first reports of ridicule directed at those granted a carte $d u$ mérite civique, Antoine-Roger Bolamba urged the selection committees to exercise caution. Many applicants, he stated, were unworthy, "caricatures of évoluants, lusting after material benefits." ${ }^{103}$ He called for stricter scrutiny of applicants' character and the addition of new criteria: the "genuine black elite" should be distinguished by their commitment to the country's advancement,

98 Letter from the governor general to the provincial governors, 31 January 1949, AA/GG/15726. Here the governor general referred to his instructions communicated in earlier letters of $10 \mathrm{Au}-$ gust 1948 and 7 October 1948.

99 Ibid.

100 Letter from the governor general to the governor of Katanga province, 17 July 1950, ARNA$\mathrm{CO} / 3 \mathrm{CC} / 113 / 592$.

101 Ngandu, "La carte d’Évolué," 198.

102 A.-R. Bolamba, "Il faudrait s'entendre," Voix du Congolais no. 32 (November 1948): 447. 103 A.-R. Bolamba, "Prudence oblige," Voix du Congolais no. 39 (June 1949): 219. 
through active membership of an association, for example. ${ }^{104}$ Correspondent Antoine-Marie Mobé assailed what he considered the unclear language of the decree when it came to the precise meaning of the term "good behaviour." $105 \mathrm{He}$ even suggested subscription to the Voix du Congolais as an additional assessment criterion: reading the newspaper was evidence of an interest in self-improvement and in helping to advance colonial development. Another author opined that the committees alone should decide who was a member of the elite through the award of the carte du mérite civique. ${ }^{106}$

The Congolese authors' discourse of virtue and need for distinction, as well as politicians' fears of resistance from the European milieu, ensured that in the colonial public sphere the carte du mérite civique was soon no longer interpreted as a way of distinguishing a broad group of the so-called detribalized. Contrary to its true purpose, now the card was to be the mark of flawless representatives of the vernacular elite. In the associated debate, the fact that a reform of immatriculation was being pursued at the same time for the few assimilated went by the board. The carte du mérite civique gained currency as a strict mechanism for selecting members of the elite. Here the concept of the elite is best understood in light of the original meaning of the French verb élire - because ultimately the elite was chosen. ${ }^{107}$ The card and the immatriculation enacted four years later were subject to a rigid colonial screening practice.

\section{Applications and selection procedures}

How did the application process for the carte du mérite civique proceed in concrete terms? What documents did applicants have to submit? What did the committees discuss in the detail? Which applications were successful and which were not? The minutes of committee meetings are a particularly good source of information on how local actors negotiated, discussed, staged and bureaucratically investigated the criteria for defining the official Congolese elite. They not only reveal what qualities the authorities demanded of this elite, but also highlight the invocation of the media ideal of the "perfected black" as a benchmark for evaluating applicants' lifeworld.

104 Ibid., 220.

105 Mobé, "A qui faut-il," 18.

106 N.n., "Nouvelle Importante,” Voix du Congolais no. 29 (August 1948): 322.

107 The word élite, used in France for a social group since the seventeenth century, is derived etymologically from the verb élire. See M. Hartmann, Elitesoziologie. Eine Einführung (Frankfurt am Main: Campus, 2004), 8. 
The decree on the carte du mérite civique itself had remained silent about exactly what the application process involved. Initially, then, there was a lack of clarity at the various administrative levels about who had to do what and by when. This prompted the General Government to standardize the procedure two years later, in June 1950, through an amendment to the decree. This clarified that interested parties had to submit their applications to the territorial official responsible for their place of residence, who would sign them. Based on his own research, the territorial official then had to produce a report within three months and present it to the district commissioner. The latter passed the report on to the relevant committee, which finally made a decision or sought additional information. The territorial official had to inform the applicant of the committee's decision within one month and state the reasons in case of rejection. The candidate could file an objection to the decision within three months. ${ }^{108}$

While this procedure meant that the final decision lay with the committee, once again it was the already overburdened territorial officials who had to do the preparatory work. In particular, they had to obtain a number of documents and references relating to applicants. They requested statements from applicants' superiors on their work ethic, but also on their private life. Their former teachers were to attest to their intellectual abilities, while the relevant chef de cité and other holders of the carte du mérite civique were to provide information on their social and public conduct. In addition, school reports and a certificate of good conduct had to be procured, often by applicants themselves, who were thus responsible for all visits to the authorities along with all the associated costs. ${ }^{109}$

Often, the report submitted by the territorial officials failed to meet the committees' requirements. In August 1950, for example, one committee complained: "In general, the committee regrets the fact that the administrative officials all too easily vouch for the candidates' level of development and civic-mindedness. [...] In practice, these 'reports' are brimming with vague information couched in stereotypical language." 110

Evidently, at times the district commissioners, that is, their superiors, who were often simultaneously chairs of the committees, instructed the responsible

108 Ordonnance $\mathrm{N}^{\circ}$ 21/229/AIMO du 24 Juin 1950, Completant l'Ordonannce $\mathrm{N}^{\circ}$ 21-258/AIMO du 12 Juillet 1948, créant une carte du mérite civique, ARNACO/3CC/113/592.

109 This emerged from the analysis of several dozen application documents submitted to the committees in the districts of Lac Léopold II and Kivu between 1949 and 1957; AA/GG/15726 and $\mathrm{AA} / \mathrm{GG} / 18708$.

110 Minutes of the district committee of Lac Léopold II on the issuing of the carte du mérite civique, 17 August 1950, AA/GG/15726. 
territorial officials to review the documents: "I want a detailed report on the candidate by 1 July 1951 at the latest. In accordance with the most recent instructions from the governor general, this report must provide evidence that the candidates are not simple évolués but are members of the ELITE."111 The committees thus demanded "guarantees of development, morality and civic-mindedness" from candidates. ${ }^{112}$ The district commissioner instructed the territorial officials to inspect applicants' homes, sound out their attitudes to colonial institutions and the "less developed natives" and verify their loyalty to the administration. ${ }^{113}$ In addition, the validity of all information was to be confirmed by a third party, culminating in a "detailed and well-founded report," which was then to be submitted to the committee. ${ }^{114}$ Let's consider a concrete example of what the application process looked like in practice. ${ }^{115}$

On 8 September 1952, the territorial official of Oshwe received a typewritten letter. Its layout resembled that of the administrative correspondence typical of the Belgian Congo: sender in the top right-hand corner of the page, recipient at the bottom right, the usual polite phrases and a handwritten signature. The reference was to the "Carte du Mérite Civique Application," below which stood:

The undersigned, Jacques K., son of Nzie, also known as Nkana (†) and Atemba (†), from the village of Mbombe, Djoko chefferie, Pendjwa sector, Kiri territory, district of Lac Léopold II, married, currently in Oshwe in the employ of the colony as an aid third-class to the territorial assistant, has the honour of respectfully requesting issuance of the Carte du Mérite Civique for Congolese of outstanding merit. ${ }^{116}$

Jacques K. pulled out all the stops of bureaucratic discourse, with which he was well familiar as an office worker. He even worked under the territorial official to

111 Letter from the district commissioner of Lac Léopold II to the territorial administrator of Oshwe, 9 September 1950, AA/GG/15726.

112 Minutes of the district committee of Lac Léopold II, 17 August 1950, AA/GG/15726.

113 District commissioner of Lac Léopold II to the territorial administrator of Mushie, 25 September 1953, AA/GG/15726.

114 Ibid.

115 I chose this example in part because it is only in the case of the committee in Lac Léopold II, an eastern district of Léopoldville province, that we have all the documents for 1951 and 1952. These include applications, correspondence and minutes. The authors of the only other publication based on the selection committees' documents used the same files; Omasomobo and Delaleeuwe, "Je veux la civilisation." It is thus an open question to what extent this material is representative.

116 Letter from Jacques K. to the territorial official of Oshwe, 8 September 1952, AA/GG/15726. Applicants for the carte du mérite civique and immatriculation identified by name have been anonymized in the present book. 
whom he had written to initiate the application process. In line with the regulations, the latter confirmed his application and affirmed that the "preparation of documents" had begun. ${ }^{117}$ Six weeks later, the territorial official wrote to the applicant requesting several documents, personal information and a detailed CV. ${ }^{118}$

Less than seven days later, Jacques K. complied with this request. He provided biographical information on his wife, mentioned his traditional Christian wedding and the birth of his first-born child, which, as fitting for an évolué, had taken place at a hospital. The 27-year-old outlined his impeccable educational career: trained as a primary school teacher by the head of the Catholic mission in Inongo, he had graduated from the petit séminaire of Bakoro. He also mentioned the various stages of his professional career: one year of teaching at a Catholic mission school, six months as a stock-keeper, four months as a court clerk and his current employment as aid to the territorial official. He also disclosed his monthly income for the current year and ownership of a small kitchen garden including 20 hens, a duck and two pigs. As requested, he enclosed school reports and certificates of employment in the dossier and provided the current addresses of his superiors and teachers to make it easier for the territorial official to write to them requesting references. ${ }^{119}$

It took six months for the territorial official to complete the dossier on Jacques K. with an excerpt from his criminal record showing that he had committed no offences, ${ }^{120}$ certified copies of his church marriage certificate ${ }^{121}$ and his primary school certificate from the école normale showing a " $\mathrm{B}$ " grade. ${ }^{122}$ The responses from third parties were also enclosed in the dossier. The candidate was claimed to be a good family man, to receive the occasional visit from the local priest, but never to get his hands dirty in his own garden, though no sources were cited. ${ }^{123}$ One of the details noted by the official on the candidate's "public life" was that he appreciated scent, but a critical remark also cropped up several times in shorthand form: "He does not mingle with the masses - he is withdrawn - he is very proud - he loathes his lower-class relatives."124

117 Letter from territorial official to Jacques K., 1 October 1952, AA/GG/15726.

$118 \mathrm{~K}$. refers to this request from the territorial administrator, made in a letter of 8 November 1952, in a reply of 15 November 1952; AA/GG/15726.

119 Ibid.

120 Excerpt from K.’s criminal record, 23 May 1952, AA/GG/15726.

121 The church wedding took place on 30 August 1948. Letter from head of the mission in Ibeke to the territorial administrator, 27 May 1953, AA/GG/15726.

122 K.'s school leaver's certificate, 1 November 1947, AA/GG/15726.

123 Report on K. by the territorial administrator, 26 May 1953, AA/GG/15726.

124 Ibid. 
It was now the task of the territorial official to evaluate the collated information. In his final report, he highlighted the candidate's high degree of education and good service in the administrative office, but gave to understand that while he behaved respectfully towards Europeans, he was arrogant in his dealings with his Congolese colleagues and treated ordinary workers with nothing short of contempt. ${ }^{125}$ The report culminated in a rather diffuse conclusion: "His life, his conduct and his manners distinguish him from the mass of other Congolese, and I repeat that he is an upright young man, but he is not part of the group of évolués and certainly cannot be considered a member of the Congolese elite."126 Before the day was out, the territorial official sent the complete dossier to the district commissioner of Lac Léopold II, who put the findings forward for discussion one month later as committee chair. ${ }^{127}$

Generally speaking, the awarding committees debated the candidates' suitability in their absence, with several usually being discussed at the same meeting. Each member had one vote, and a simple majority was sufficient to decide on the application. ${ }^{128}$ The committee was only quorate if at least five of its members were present, but these always had to include a holder of the carte du mérite civique and a representative of the territorial administration. ${ }^{129}$ The committee could endorse or reject the application. A third option was to defer the decision, either if it was thought necessary to obtain more information or if the applicant was rated as not yet mature but potentially apt. In this case he was asked to reapply at a later time.

The committee meeting on Jacques K.'s application took place in Inongo, the administrative seat of the district of Lac Léopold II. ${ }^{130}$ Nine locally resident members were in attendance, who knew the candidate only from the documents. First, the committee chairman reported on the dossier submitted by the territorial official and read out the latter's assessment of the candidate. He then asked the members for their views. The first to state their opinion were the two Congolese representatives. The assessment of the teacher at the école normale of Inon-

125 Report on K. by the territorial administrator, 29 May 1953, AA/GG/15726.

126 Ibid.

127 Letter from the territorial administrator to the district commissioner of Lac Léopold II, 29 May 1953, AA/GG/15726.

128 Ordonnance $\mathrm{N}^{\circ}$ 21/258 AIMO du 12 Juillet 1948 créant une carte du mérite civique, reprinted in Voix du Congolais no. 30 (September 1948): 363.

129 Ordonnance $\mathrm{N}^{\circ}$ 21/229/AIMO du 24 Juin 1950, Completant l'Ordonannce $\mathrm{N}^{\circ}$ 21-258/AIMO du 12 Juillet 1948, créant une carte du mérite civique, ARNACO/3CC/113/592.

130 The following section refers to the minutes of the district committee of Lac Léopold II on the issuing of the carte du mérite civique, 27 June 1953, AA/GG/15726. 
go, whose appraisal of the dossier was essentially negative, because the candidate's arrogance towards his fellows suggested that he should not be issued with a carte du mérite civique, was backed by the warden of the CEC of Inongo. A European representative of the CEC administration took the same view. A Belgian doctor, on the other hand, highlighted the inconsistencies in the dossier and defended Jacques K.'s alleged aloofness on the basis that he was not from the region, which hampered his integration into the local community. As he saw it, the candidate's "excellent private conduct" spoke in his favour. The local public prosecutor backed him in this, contending that one could not refuse the carte du mérite civique on the basis that the candidate avoided the basengi, that is, uneducated Congolese.

Given that the committee had come to no clear view, the chairman pointed out that not everyone could receive such an important honour as the carte $d u$ mérite civique. The territorial administrator of Inongo also came out against the candidate: at the end of the day the goal was to choose "the elite of the elite." He also pointed out that a careless selection would attract sharp criticism. The territorial official explained further that the candidate ought to be rejected not just because of his attitude towards ordinary workers, but also due to an incident, omitted from the dossier, in which he had been guilty of "public intoxication.” As a result of the differing opinions among the committee members, no final decision was made about this applicant.

Ten months after Jacques $\mathrm{K}$. had submitted his application to the local territorial administrator, he had to pay a visit to the latter in person to hear the committee's decision. In front of him lay the letter explaining that due to his social conduct he could not yet be counted among the elite:

The committee takes the view that Mr K.'s private conduct and professional activity are impeccable. His social behaviour, meanwhile, chiefly towards those at or below his level, must be improved. He is highly commendable but not yet a member of the elite. The candidate's application may be reassessed after two years. ${ }^{131}$

The letter, signed by Jacques K., was sent back to the district commissioner. There are no sources available to clarify whether he made a second attempt two years later, whether the demands for further perfecting discouraged him or spurred him on, or whether he altered his social behaviour - or whether the objections raised during the committee meeting were well-founded in the first place.

131 Minutes on K.'s application delivered by post, 22 July 1953, AA/GG/15726. 
A social distance from uneducated Congolese was also cited in other committee minutes as grounds for rejection. One applicant, whose reading of the Voix du Congolais and Croix du Congo, regular visits to the local library and nicely furnished home were attested by the territorial official, failed to pass muster with the committee twice within just three years due to his incorrigibly "snooty behaviour." 132 But the committees also identified other reasons why applicants were unworthy of the card.

Antoine P. submitted his application as the first candidate from the territory of Mushie. ${ }^{133}$ The territorial official's investigative report stated that, as a doctor's assistant, the candidate had dealings with "natives" on a daily basis and treated them "humanely." ${ }^{134} \mathrm{He}$ had also been elected president of the local évolué association. ${ }^{135}$ His education, on the other hand, was unremarkable when compared with others practising the same profession. Outweighing everything else, however, was the picture the official painted of his visit to the applicant's home. The following description shows that the official must have put every corner of the house under the microscope:

Living room and dining room clean and tidy. Bedrooms quite untidy and obstructed by various objects. Kitchen separate from the dwelling; grime in evidence; leftover food everywhere; there is a strong smell here. [...] Furnishings: very respectable in the living room and dining room. Fairly primitive in the bedrooms. Kitchenware: does not give the impression of being cleaned regularly. ${ }^{136}$

So while the official was satisfied with the lounge, so omnipresent in the media imagery of the perfect évolue family, and the dining room, he was disturbed by the state of the kitchen and bedrooms, which he evidently felt able to enter without violating the applicant's privacy.

The criticism of Antoine P.'s household was ultimately a criticism of his wife. The entry on her "degree of development" stated: "Not applicable. Not attending a course on household refinement." ${ }^{\text {"137 }}$ As we saw earlier, there was a tradition of inspection visits of this kind in the Belgian Congo, most of them carried out by

132 Minutes of the district committee of Lac Léopold II on the issuing of the carte du mérite civique, 7 March 1953, AA/GG/15726.

133 Letter from P. to the territorial administrator of Mushie, 10 August 1953, AA/GG/15726.

134 Detailed report on P. by the territorial administrator of Mushie, 13 November 1953, AA/GG/ 15726.

135 Namely the Cercle Colonel Chaltin; see Activité des cercles, Voix du Congolais no. 96 (March 1954): 231.

136 Report on P. by the territorial administrator of Mushie, 13 November 1953, AA/GG/15726. 137 Ibid. 
the (female) heads of the foyers sociaux to appraise their students' learning progress. In a context in which the state of one's home helped determine whether one was issued with a carte du mérite civique, it is not hard to understand why members of the vernacular elite were so keen for their wives to attend the household management schools. ${ }^{138}$ Women played a key role in staging an impeccable évolué existence. As the authorities sought to assess whether individuals had internalized ideas about what constituted a civilized lifestyle, the private sphere became subject to public discussion and scrutiny.

In addition, home visits, which were carried out by the territorial official but in some places also by staff of the foyers sociaux or the chef de cité, were meant to clarify whether the candidate was using enough of his salary on his household. The reports read like inventories of material possessions:

In the living room there are 1 table, 7 chairs, 1 table with a gramophone, 1 kitchen cupboard containing several household appliances. A cover on the table. In the living room a side table and 4 armchairs and 4 small side tables, 1 table with a radio, 1 large rectangular mirror. [...] Everything is clean. Cushions on the armchairs, curtains on windows and doors, table covers and wall decoration. ${ }^{139}$

Nonetheless, the inhabitant of this dwelling, described in such detail and highly praised, was denied the carte du mérite civique. For even the loveliest of furnishings could not make up for the flaw identified in the territorial official's report. For a lengthy period, in addition to his longstanding marriage, the candidate maintained a relationship, of which few were unaware, with another woman; he had even had a child with her. ${ }^{140}$ Although the candidate apologized to the territorial official for having kept quiet about this child, ${ }^{141}$ the committee's judgment on the otherwise flawless application was unequivocal: "His character is that of the man-about-town, who has a lover everywhere he goes and drinks a great deal," ${ }^{142}$ to quote one committee member's final conclusion.

Well aware that the practice of polygamy was an obstacle to obtaining the carte du mérite civique, many candidates kept quiet about such relationships in their application. Attempts at concealment often did the rounds at committee meetings, prompting the authorities to urge the territorial officials not to rely on

138 Interview with Jean de la Croix Mobé, Kinshasa, 1 September 2010; interview with Jean Lema, Kinshasa, 13 August 2010.

139 Report on Benoît C. by the territorial administrator of Kiri, 7 July 1953, AA/GG/15726.

140 Ibid.

141 Letter from C. to the territorial administrator of Kiri, 2 July 1953.

142 Minutes of the district committee of Lac Léopold II on the issuing of the carte du mérite civique, 7 August 1953, AA/GG/15726. 
applicants' statements. Instead, through a "thorough investigation of [candidates'] private lives" they were supposed to check whether they did not in fact have a "lover."143

Rumours of applicants with several marriage-like relationships were thus far from rare. One former mission school teacher on another selection committee, for example, who had known a candidate since childhood, confirmed that while he was one of his "best pupils," recently his wife had confided in the pastor that her husband's identity card recorded an "illegitimate child." ${ }^{144}$ It is no coincidence that the comprehensive screening of applicants' lives even included confidential information revealed to clergymen. The missionaries were still the supreme custodians of the évolués' monogamous nuclear families. This time, however, the candidate's written statement, composed in the style of a confession, persuaded the committee not to permanently deny him a card. Deploying the language of perfectibility, the letter evoked the desire, required of all applicants, to attain a higher level of civilization against all the odds:

I regard my behaviour as extremely flawed, as I was married according to Christian tradition, and I promise to take serious steps to improve myself, for the sake of my own uprightness and to ensure the peace of mind of my wife and children. Please believe me when I say that I have betrayed my wife just once in fifteen years of marriage. I leave it to your judgment whether you grant me a distinction I am no longer sure I am even entitled to. ${ }^{145}$

On some occasions, in fact, the committee learned of the candidate's alleged polygamy only after it had issued a carte du mérite civique. This applied to one of the first men to be granted this distinction by the committee in the district of Lac Léopold II, and the first in the Belgian Congo whose card was withdrawn. ${ }^{146}$ The individual in question was Patrice S., a doctor's assistant. Before the territorial official had even set a date for the public conferment of the carte du mérite civique, in September 1950 the district commissioner instructed him to withdraw it

143 Letter from the district commissioner of Lac Léopold II to the territorial administrators, 9 January 1950, AA/GG/15726.

144 Letter from the mission school teacher in Inongo to the territorial administrator of Lac Léopold II, 2 July 1953, AA/GG/15726.

145 Letter from Jean T. to the territorial administrator, 5 July 1953, AA/GG/15726.

146 This emerges from official statistics on the carte du mérite civique, which list all successful and unsuccessful applications, as well as withdrawn cards, by territory. Chambre des représentants, Rapport sur l'administration de la colonie du Congo Belge pendant l'année 1950 présenté aux chambres législatives (Brussels: Ministere des affaires africaines, 1951), 111; Rapport annuel AIMO District Lac Léopold II 1951, ARNACO/AIMO/73CC/73/157. 
from Patrice S. for one year. ${ }^{147}$ Shortly before, doubts had been raised about the candidate at a committee meeting. For after his distinction had been announced, the territorial official received an anonymous letter alleging that Patrice S. had two lovers; the head of the local mission, at least, was able to confirm this. In addition, two weeks after the committee's positive decision on 20 December 1949, S. was fined: he was accused of having violated the nightly curfew for Congolese on 31 December and to have been found in a state of mild drunkenness. ${ }^{148}$

It is quite possible that Patrice S. was celebrating the award of the carte $d u$ mérite civique on New Year's Eve. His misfortune, however, was that for holders of the card the nightly curfew was only abolished eighteen months later. ${ }^{149}$ The committee chair's wish to deprive him of the card permanently, however, was voted down by a majority of the members. ${ }^{150}$ When the case came before the committee again one year later, the additional investigations, which the territorial official had been expressly instructed to carry out, ${ }^{151}$ favoured Patrice S. and refuted the accusations made against him. In July 1952, he was reissued with his carte du mérite civique.

In total, the committees demanded the return of the carte du mérite civique only from one in fifty of the 1,557 status holders. ${ }^{152}$ This may be numerically insignificant, but it is indicative of the logic of the official process of appointment to the elite. It allows us to infer that in general the carte du mérite civique represented a highly fluid status. It could be revoked and was in a sense awarded on probation. Just as, in colonial discourse, the évolués' development towards a civilized lifestyle was regarded as unstable, this legal category was also unstable in design. It amounted to provisional assimilation. The expectation that évolués were likely to regress meant that holders of the carte du mérite civique had to incessantly prove that they were worthy of this legal category.

147 Letter from the district commissioner of Lac Léopold II to the territorial administrator of Mushie, 9 September 1950, AA/GG/15726.

148 Minutes of the district committee of Lac Léopold II on the issuing of the carte du mérite civique, 17 August 1950, AA/GG/15726.

149 List of the benefits and rights provided by the carte du mérite civique (as at December 1952), GG/AI/4743/II/T/4.

150 Minutes of the district committee of Lac Léopold II on the issuing of the carte du mérite civique, 17 August 1950, AA/GG/15726.

151 Letter from the district commissioner of Lac Léopold II to the territorial administrator of Mushie, 9 September 1950, AA/GG/15726.

152 My own calculations, based on the colonial administration's official figures, suggest that by the end of 1958 a total of 42 out of 1,557 holders of the carte du mérite civique had had theirs withdrawn. See annual statistics for the period 1949-1959: Chambre des représentants. 
To sum up, the selection committees mistrusted the applicants, listened to rumours and malicious gossip and encumbered the candidates with a hard slog that was both protracted and expensive. Above all, they required applicants to permit inspection of intimate spheres of life. The committees subjected applicants to a "maturity test," a litmus test of cultural bourgeoisification. What Antoine-Roger Bolamba in the Voix du Congolais demanded of future holders of the carte du mérite civique, namely that the "black elite must be capable of everything,"153 the committee members made the benchmark for their decisions.

Domesticity, a monogamous marriage, a civilized gender order, exemplary conduct, sensible leisure-time activities, rational consumption: these leitmotifs of the media discourse of self-reassurance among Congolese authors were also key themes in the committees. They were translated into a catalogue of criteria, produced by the committees with bureaucratic meticulousness, which applicants had to satisfy in order to obtain the carte du mérite civique. The selection process was, so to speak, collateral damage caused by authors' normative discourse on perfectibility, which had helped them lend weight to their demands. The perfidious thing about this was that the demands an aspiring elite made of itself contributed to this strict selection. In order to be officially appointed a member of the Congolese elite, moreover, it was not enough to be a conscientious worker or faithful husband, to aid the indigènes in their cultural development or to maintain a household beyond reproach. Applicants had to comply with all these requirements and more besides. The desire to be attributed to a higher level of civilization by obtaining the carte du mérite civique might come to nothing due to a lack of clean cutlery.

\section{The colonial maturity test}

Though so far it has seemed as though applicants bowed to a prescribed procedure, the application and selection processes were not a performance in which candidates played merely a minor role. Certainly, the sources prohibit systematic investigation of how applicants sought to positively influence this process, but they are sufficient to establish that this did occur.

As the examples discussed earlier showed, some applicants kept quiet about their lovers or illegitimate children by opting not to register them in their official

153 A.-R. Bolamba, “L’Elite Noire,” Voix du Congolais no. 44 (November 1949): 416. 
documents. ${ }^{154}$ Whether they succeeded in strategically feigning monogamy, and if so on what scale, must remain unclear. It is inherent in attempts at concealment that only the unsuccessful cases are documented.

There was an unhappy outcome for one candidate who attempted to convince the committee of his above-average education with a falsified school report, which came to light after he had been awarded the carte du mérite civique. The subsequent forced return of the card seems an even more bitter blow given that proving one had completed school was not an explicit criterion, though in practice it improved one's chances of success. ${ }^{155}$

Less risky than falsifying documents were attempts by applicants to fix up their homes for inspection. Particularly when the date of a home visit had been set, furniture was borrowed from friends, while the house was tidied and cleaned. ${ }^{156}$ These stagings of exemplary bourgeois domesticity, however, required all members of the family to play along, which was markedly more difficult if differing everyday habits existed within a family.

The novel Les hauts et les bas by Batukezenga Zamenga, published in 1971, tells of the family conflicts experienced by the main character in the course of his application for immatriculation. ${ }^{157}$ Written from the anti-colonial perspective of Zaïrization in the 1970s, when President Joseph-Désiré Mobutu replaced all names of colonial origin with supposedly authentic African ones, ${ }^{158}$ the novel interprets the embrace of a European lifestyle as a process of increasing alienation from one's own traditions. Guided by this cultural dichotomy, the author conceptualizes the husband and wife as a contrastive pair: on the one hand we have the male protagonist, who moves to Léopoldville after finishing school and poses as an évolué, and on the other his wife, a woman from the village who has brought her habits along with her.

The author describes the protagonist's application for immatriculation as a series of "difficult initiation rites." 159 At the recommendation of his European su-

154 Having a religious wedding became a strategy through which future applicants for a carte du mérite civique could improve their chances: it eventually got about that the committees often requested a statement from the local missionaries, whose opinion carried weight when it came to making a decision; A.-A. Ngeke, "La carte du mérite civique scindera-t-elle la classe des évolués?,” Voix du Congolais no. 140 (November 1957).

155 Correspondence from the deputy king's procurator in Buta to the king's procurator in Stanleyville, 26 September 1951, AA/GG/21875.

156 Tshonda and Delaleeuwe, "Je veux la civilisation," 840-841.

157 B. Zamenga, Les hauts et les bas (Kinshasa: Médiaspaul, 1971), 54-60. On the author’s work, see Riva, Nouvelle histoire, 131-133.

158 On Zaïrization, see Van Reybrouck, Congo, 417-427.

159 Zamenga, Les hauts, 54. 
perior, he changes his lifestyle in order to satisfy the committee members. Henceforth, he stays away from bars and dresses according to "évolué fashion" - "his tie becomes a permanent fixture, regardless of circumstance or climate"; ${ }^{160}$ he also joins the church choir and speaks only French.

Yet his self-staging as a "genuine" évolué fails due to his wife's traditional way of life. She not only refuses to adopt the European habit of sitting next to one's husband on the pew, but also to modify her approach to everyday family life. She resists the demand to eat European meals together at the table as a family. While her husband eats in the house, his wife and children continue to sit on the ground outside, eating from a bowl. The couple finally reaches a compromise: they eat at the dining table in the living room only on Sundays, when the committee representatives usually visit people's homes. The author of the novel, however, has this performance exposed as the home visit takes place on a Thursday, when the family is eating in the traditional way: the children cry when their father, unnoticed by the territorial administrator, manoeuvres their fufu into the dustbin. When another unannounced home visit takes place late in the evening, the protagonist is hosting a number of relatives from the village, who are spending the night on mats in the living room. For the selection committee, this incident is evidence enough that the candidate is captive of traditional notions of family. They thus refuse to grant him immatriculation.

The novel lays bare the familial conflicts that occur during the application process for évolué status, which could be triggered by the authorities' attempts to investigate whether a candidate fit the ideal of the "perfect black." Furniture could be arranged more easily than family members.

A change of status, then, was possible chiefly for those Congolese men who, as master of the house, could ensure a gendered and domestic order informed by bourgeois precepts. Many applicants feared the associated scrutiny of the private sphere. Today, contemporary witnesses still view this as symbolic of the profound humiliation suffered by the vernacular elite.

Other applicants, meanwhile, went out of their way to invite committee members to inspect their homes in order to showcase their civility. AntoineMarie Mobé, for example, mentioned several times already as an active association president and press correspondent, informed the committee chair that anyone could see for themselves, at any time, that he was performing his everyday duties as family man and husband:

Please note that as yet I am probably the only father who - in possession of a small blackboard, recognizable from the street when the windows are open - attends to the education

160 Ibid., 55. 
and edification of his children during the evening. Furthermore, I am probably the only husband who has taught his wife to read and write. ${ }^{161}$

Mobé's case, however, is less an example of applicants' subservience than of how they proactively laid claim to elite status. Mobé had already submitted his application for a carte du mérite civique during his time in Stanleyville. ${ }^{162}$ The application procedure, however, was temporarily suspended, probably in connection with his conflicts, as association president, with the local colonial administration, which was responsible for the assessment of his dossier. ${ }^{163}$ In any event, Mobé resubmitted his application in Coquilhatville only after he had moved there in 1953. Having once again received no response of any kind from the local committee, Mobé broke with the conventions of official protocol, which demanded reserve and patience of applicants, as communication with the committee could occur only indirectly through the territorial official. Mobé repeatedly wrote to the committee chair in person, providing unsolicited arguments for a positive decision. ${ }^{164}$ He disposed of possible doubts by enclosing in one letter the court decision absolving him of the embezzlement of which he had previously been accused. ${ }^{165} \mathrm{He}$ forwarded current work evaluations and emphasized that he was no simple office assistant: he now sat "at the same table with the Europeans" and took on the tasks of his European superiors, who he even stood in for when they were absent. ${ }^{166}$

For Mobé, the carte du mérite civique was not something that he wished to ask the committee for. He laid claim to it. "What else?,"167 he asked after listing his own merits. When, after three years of waiting, he had received no response, in late 1956 he wrote sarcastically:

161 Letter from Antoine-Marie Mobé to the chair of the committee in Coquilhatville on the issuing of the carte du mérite civique, 17 December 1956, private archive Antoine-Marie Mobé. 162 Ibid.

163 Mobé spoke of "specific circumstances that have made it necessary to postpone my application for a certain amount of time"; ibid.

164 Letters from Mobé to the chair of the committee in Coquilhatville on the issuing of the carte du mérite civique, 19 October 1956, 17 December 1956 and 31 December 1956, private archive Antoine-Marie Mobé.

165 Letter from Mobé to the chair of the committee in Coquilhatville on the issuing of the carte du mérite civique, 19 October 1956, private archive Antoine-Marie Mobé.

166 Letter from Mobé to the chair of the committee in Coquilhatville on the issuing of the carte du mérite civique, 17 December 1956, private archive Antoine-Marie Mobé.

167 Ibid. 
I have the honour of reminding you once again to kindly let me know whether the relevant committee, otherwise to be found everywhere, exists in Coquilhatville as well. In view of the time that has elapsed since my first appeal, I am forced to conclude that there is in fact no such committee here in Coq. ${ }^{168}$

Finally, Mobé's persistence and systematic self-portrayal as a "genuine" évolué paid off: on 13 June 1957, he received his carte du mérite civique. ${ }^{169}$

So far, I have focussed on the applications and selection procedure involved in the carte du mérite civique. But how did things stand in the case of immatriculation? Because this status conferred greater legal benefits, namely equality with Europeans under civil law, the General Government demanded that candidates satisfy even more stringent conditions and undergo a particularly strict selection process. A decree of 17 May 1952 specified the following conditions: "Proof of an education and way of life of a civilizational level that allows one to enjoy one's rights and fulfil one's obligations as provided for in the written legislation." "I70 much the same way as with the carte du mérite civique, when granting immatriculation the authorities were keen for applicants to demonstrate a lifestyle consonant with prevailing notions of civility.

In contrast to the carte du mérite civique, the application process for immatriculation did not lie in the hands of a selection committee. Because this was a matter of conferring civil rights, it was the courts that made the decision. It was thus the king's procurator responsible for a particular province who dealt with the applications. He revealed candidates' identity through a "public notice" that took the form of announcements in the press and notices outside administrative offices. ${ }^{171}$ This text requested submission of information on, and objections to, applicants within two months. ${ }^{172}$ Once again, it was the territorial official's task to produce a detailed report and compile similar information as in the case of applications for the carte du mérite civique. ${ }^{173}$ At a court sitting, the judge,

168 Letter from Mobé to the chair of the committee in Coquilhatville on the issuing of the carte du mérite civique, 31 December 1956, private archive Antoine-Marie Mobé.

169 Letter from the territorial administrator of Coquilhatville to Mobé, 7 June 1957, private archive Antoine-Marie Mobé.

170 Decree on immatriculation of 17 May 1952, reprinted in Croix du Congo (13 July 1952).

171 P. Lumumba, Le Congo, terre d'avenir, est-il ménacé? (Brussels: Office de Publicité, 1961), 64. 172 The avis au public were regularly published in the Voix du Congolais. See for example A. Decoux, “Avis du Public,” Voix du Congolais no. 79 (October 1952): 597.

173 This meant compiling information on the professional, moral and familial aspects of applicants. See, for example, the letter from the king's procurator in Stanleyville to the territorial administrator in Stanleyville, 6 July 1954, AA/GG/11096. 
together with four specially appointed assessors, decided whether to award immatriculation in each case. ${ }^{174}$

Further, unlike the carte du mérite civique, immatriculation applied not just to the applicant individually but also to his wife and children. It was not, therefore, an individual who applied for immatriculation, but a family. In French Africa too, until the late 1940s the most important criterion for switching from the indigénat to citizenship had been the family: as the nucleus of society, it was allocated the task of handing down "those qualities of 'civility' considered specific to French civilization and essential to incorporation into French society."175

In the case of candidates for immatriculation, then, the court's critical gaze was directed primarily at their wives. The guiding ideal here was not the "radically modern phenomenon of the emancipated woman who enjoys equality with men," but rather a traditional Catholic conception: "We must be satisfied if she makes a good wife, good mother and good housewife in equal measure," stated Antoine Sohier as the main figure responsible for planning reformed immatriculation. ${ }^{176}$ The public prosecutors of the Belgian Congo were informed in the Journal des tribunaux d'outre-mer, edited by Sohier, of how immatriculation was to be implemented and how to assess wives' capacity for education. They were also to evaluate whether the children had good enough French and sufficiently "civilized practices" to keep up at a European school. ${ }^{177}$ The application process for immatriculation included personal attendance at court, where husband and wife both had to justify themselves before a jury:

The applicant and his wife undergo a brief interrogation, which entails complex queries and a number of loaded questions, including: What do you understand by the term immatriculation? What legal benefits does immatriculation entail? In case of a domestic dispute, do you leave your husband to seek refuge with your aunts? What do you do with the money your husband earns? ${ }^{178}$

174 The decree stipulated that there had to be enough assessors for every district, always including two territorial officials and a Congolese already granted immatriculation. See decree on immatriculation of 17 May 1952, reprinted in Croix du Congo (13 July 1952); letter from the governor of Équateur province to the head of the General Government's AIMO department, $16 \mathrm{Au}-$ gust 1952, AA/GG/10211.

175 See Gosewinkel, Schutz und Freiheit?, 309.

176 A. Sohier, "Immatriculation des indigènes," Journal des tribunaux d'outre-mer 39, 13 September 1953, 96.

177 A. Sohier, "Immatriculation des indigènes," Journal des tribunaux d'outre-mer 41, 15 November 1954, 108.

178 Lumumba, Congo, terre d'avenir, 65. 
This is how Patrice Lumumba described attendance at court, which scrutinized not just applicants' bourgeois lifestyle and their families' "civilized" gender order, but also their understanding of European law. ${ }^{179}$

Lumumba spoke from experience. He was one of the first to be granted immatriculation, submitting his application in August 1952, less than three months after the introduction of the reform. ${ }^{180}$ But it was to be two years before he was awarded this status. Lumumba is not only an example of the flawless image candidates had to convey to attain immatriculation, but also of the references and networks that could help them do so.

After submitting his application, Lumumba first made a great effort to bolster his CV. At the post office in Stanleyville, he rose from the lowest to the highest rank of Congolese office assistant within sixteen months. ${ }^{181} \mathrm{He}$ also advanced within the associational world of Stanleyville. Between December 1953 and March 1954, he took over the presidencies of the AES, the local branch of the ADAPES and the Amicale de Postiers Indigènes de la Province Orientale; in April 1953, he became secretary of the Association du Personnel Auxiliaire de la Colonie. ${ }^{182}$ During the two years of the application process, Lumumba published thirty-one articles in the Croix $d u$ Congo and three more in the Voix du Congolais. ${ }^{183}$ He also volunteered at the Bibliothèque Publique pour Congolais.

As if this was not enough, in a eulogy to Henry Morton Stanley on the fiftieth anniversary of his death Lumumba played up to Belgium's perception of its colonialism as a philanthropic endeavour, while keeping quiet about the bloody chapters in the explorer's biography: "Stanley brought us peace, gave us human dignity, improved our material lives, nurtured our intellect and developed our soul."184 The Voix du Congolais printed this speech, given at the AES, verbatim, thus painting a picture of an eloquent and loyal évolué. ${ }^{185}$ Lumumba also gained the support of French sociologist Pierre Clemens for his application for immatriculation. ${ }^{186}$ Off the back of Lumumba's role as research assistant, a

179 Ibid.

180 Letter from J. Orbaen, king's procurator in Stanleyville, to Patrice Lumumba, 4 September 1952, property of the Treves family.

181 Lumumba was promoted to office worker second-class on 11 October 1952 and entered into the first class on 1 July 1954; Mutamba-Makombo, Patrice Lumumba, 72.

182 Ibid. The Voix du Congolais published an encomium to Lumumba, along with his portrait; A. Songolo, “M. Patrice Lumumba à l'honneur,” Voix du Congolais no. 106 (January 1955).

183 Figures derived from the list of publications drawn up by Jean-Marie Mutamba-Makombo; Mutamba-Makombo, Patrice Lumumba, 57-65.

184 P. Lumumba, “Un explorateur incomparable,” Voix du Congolais no. 100 (July 1954).

185 Ibid.

186 Letter from Réné Rom to Lumumba, 28 August 1954, property of the Treves family. 
friendship took off that even found expression in the naming of his son, born in September 1952, who was christened Patrice Pierre Clemens Lumumba. His circle of European supporters also included Réné Rom, a locally resident liberal lawyer and adviser to the AES. In particular, Rom lent Lumumba support when, after his first application for immatriculation was rejected, he turned to the Court of Appeal in Léopoldville. ${ }^{187}$ When Lumumba was granted immatriculation at the second attempt, ${ }^{188}$ he had not only invested his hard-won cultural and social capital, but also his money: the court costs in Léopoldville came to 1,180 francs, equating to about half the monthly earnings of an office worker in the colonial administration. ${ }^{189}$

Lumumba's case lays bare the sweeping requirements applicants for immatriculation had to satisfy, regardless of where they lived in the Belgian Congo. One of the first individuals to be immatriculated in Léopoldville had served with the Force Publique in Madagascar and Burma during the Second World War, after which he became president of the Association des Anciens Combattants and a member of the advisory committee of the Voix du Congolais. ${ }^{190}$ In Bukavu, the couple T. also satisfied the jury in every respect. Jules T. had completed the petit séminaire before continuing his education at evening schools. He was a "first-class office worker" and highly regarded by his employers. Active in seven associations as member or president, he also sat on advisory bodies within the colonial administration, such as the Conseil de Province du Kivu and the Conseil de Gouvernement. ${ }^{191} \mathrm{He}$ had a considerable sum in his savings account and had paid off the loan he had taken out to buy his house. In addition, not only had he already received the carte du mérite civique, but so had his wife, making "Mrs Jules T." one of the few women to be granted the card. ${ }^{192}$ Court records on another applicant from Léopoldville mention a stay in Belgium and training as a priest

187 Letter from Rom to Lumumba of 28 August 1954 and 13 September 1954, property of the Treves family. Section III, article V of the decree on immatriculation permitted applicants to appeal: decree on immatriculation of 17 May 1952, reprinted in Croix du Congo, 13 July 1952.

188 This occurred on 5 August 1954. For the announcement of the decision, see Journal des tribunaux d'outre-mer 55 (15 January 1955): 22.

189 Letter from Réné Rom to Lumumba, 13 September 1954, property of the Treves family. On earnings, see Mutamba-Makombo, "Les évolués," 92.

190 "Immatriculation des indigènes, conditions, 1er instance Léopoldville, 27 July 1953,” Journal des tribunaux d'outre-mer 43 (15 January 1954): 162.

191 On this section, see M. Dermaut, “Chronique judiciaire: L'Immatriculation,” Journal des tribunaux d'outre-mer 43 (15 January 1954): 28-29.

192 See Comité de l'A.P.I.C., "Au tableau d'honneur de l'elite noire remise des Cartes de mérite civique,” Voix du Congolais no. 48 (March 1950): 163-164; E. B. Chirishungu, “Au tableau d'honneur de l'elite," Voix du Congolais no. 74 (May 1952): 302-303. 
at the grand séminaire, while another candidate is documented as having attended the Colonie Scolaire in Boma and helped edit the Voix du Congolais and Mbandaka. The emphasis in another case, meanwhile, was on the candidate's investment of his savings in the building of a "house of durable materials, pleasantly furnished and properly maintained."193

In brief, the immatriculated bore impressive testimony to the cultural bourgeoisification of their entire family. They satisfied the jury that they were propagating the ideal of the Congolese elite, and not just in the media: in their everyday lives too, they were convincing embodiments of the "perfected black."

\section{Social profiles and success rates}

Beyond case studies, what can we say about the number and profile of applicants and those selected? What was the ratio of successful to failed applications? Did those allocated to the different legal categories have specific characteristics? Were there differences between the carte du mérite civique and immatriculation?

First, we should recall that ever since it flared up at the end of the Second World War, the debate on évolué status had revolved around who ought to benefit from it. Both European and Congolese actors long disagreed on whether the target group should be narrowly or broadly defined. With the declared goal of preventing the formation of an isolated elite caste, in July 1948 the colonial minister opted for an inclusive solution in the shape of the carte du mérite civique. This he linked with the recognition of an "open class," those "natives" whose education and culture took their lead from European models but without necessarily belonging to the elite. ${ }^{194}$ The Voix $d u$ Congolais reinforced this reading, stating that the carte du mérite civique was not intended solely for the "category of office assistants," but that even the illiterate could apply: "It should be granted to all those who have made serious efforts to develop." 195

Despite all the avowals, ultimately it was the educated and professionally successful candidates who made up the majority of successful applicants. A statistical analysis of different social groups shows that by late 1951 three out of four cartes du mérite civique went to the so-called "native brain workers": 290 out of

193 “Chronique judiciaire, L'Immatriculation," Journal des tribunaux d'outre-mer 54 (15 November 1954): $108-109$.

194 Speech by the colonial minister on the introduction of the carte du mérite civique, reprinted in "Chronique de la vie indigène et nouvelles diverses," Voix du Congolais no. 28 (July 1948): 303-306.

195 Bolamba, "Carte du mérite," 360. 
398 cards in absolute figures. ${ }^{196}$ The reports on cardholders published in periodicals such as the Voix du Congolais shed light on the professions covered by this term and indicate that this group consisted chiefly of office workers, doctor's assistants and mission school teachers, in other words the typical évolué occupational groups, which required a high level of education. In the first seven years after the introduction of the carte du mérite civique, a total of 228 individuals were mentioned in the Voix du Congolais, of whom half were office workers. ${ }^{197}$ This is unsurprising given that, as a rule, office workers were recruited from the best schools in the country. They were the likeliest to have the kind of cultural and social capital that promised success when applying for a carte du mérite civique. Further, it was mainly office workers employed by the colonial administration who were encouraged to submit an application by their European employers. ${ }^{198}$

What other groups were granted the carte du mérite civique? By 1952, "skilled and low-skilled workers," at 51 individuals, made up a not insignificant 13 percent. One in three of this group was from the most heavily industrialized region of Katanga, where there was a greater need for trained manual workers. ${ }^{199}$ These included carpenters, mechanics, but also stock-keepers. ${ }^{200}$ At 23 individuals, 6 percent of cardholders were in the category of "native authorities." As so-called chefs, they were tasked with police work for the colonial administration at the lowest level of territorial unit. Self-employed tradesmen and retailers, at 19 individuals, received just 4 percent of cards issued, an indication of the marginal position of Congolese in the colonial economy. Only the category of "women" did worse, at 12 cards. ${ }^{201}$ Tellingly, press reports on women cardholders always referred to the "wife of." ${ }^{202}$ In line with their limited educational opportunities and

196 Chambre des représentants, Rapport 1951, 101. Unfortunately, only the report for 1951 includes such detailed statements about cardholders' social profile. Other authors have also made reference to this report; Mutamba-Makombo, "Les évolués," 81.

197 My calculation, based on systematic perusal of 63 issues of the Voix du Congolais (from no. 28 of July 1948 to no. 111 of June 1955). Measured against the 1,258 individuals with a carte du mérite civique, up to that point the figure had been one in five. On the total number of those granted this distinction by then, see Chambre des représentants, Rapport sur l'administration de la colonie du Congo Belge pendant l'année 1956 présenté aux chambres législatives (Brussels: Ministere des affaires africaines, 1957), 94.

198 Interview with Mwissa Camus, Kinshasa, 24 August 2010.

199 Chambre des représentants, Rapport 1951, 101.

200 My calculation, based on systematic perusal of 63 issues of the Voix du Congolais (from no. 28 of July 1948 to no. 111 of June 1955).

201 Chambre des représentants, Rapport 1951, 101.

202 “Au tableau d'honneur de l'élite congolaise,” Voix du Congolais no. 59 (February 1951): 86. 


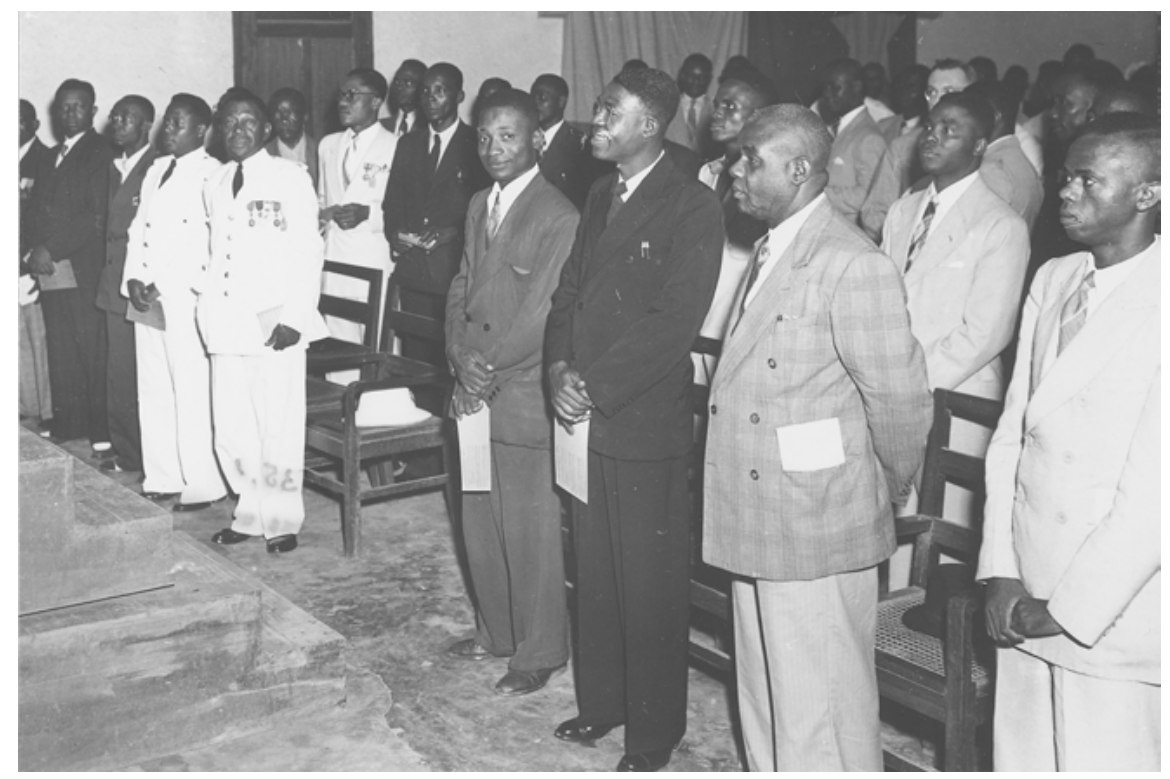

Fig. 13: Awarding ceremony for the cartes du mérite civique in Léopoldville, 1950. At the centre of the picture Antoine-Roger Bolamba, editor-in-chief of the Voix du Congolais, is looking at the camera.

associated exclusion from the colonial working world, for the most part officially approved elite women could earn merit only as exemplary housewives. Overall, one out of every two cartes du mérite civique was granted to male office workers with an above-average education.

These figures reveal that allocation practices contradicted the intention of colonial policy to distinguish an "open class" ${ }^{203}$ through the carte du mérite civique. Just under a year after the card's introduction, the Voix $d u$ Congolais was already pointing out that many illiterate people had neither heard of the card nor been informed about the criteria for obtaining it. ${ }^{204}$ But even among the literate there was widespread ignorance about exactly what was involved. At times, interested individuals asked the district commissioner, with the utmost politeness, to inform them of the criteria, and were referred to the General Govern-

203 Speech by the colonial minister on the introduction of the carte du mérite civique, reprinted in “Chronique de la vie indigène et nouvelles diverses," Voix du Congolais no. 28 (July 1948): 304. 204 Bolamba, "Prudence oblige," 220. 
ment's decree. ${ }^{205}$ Other newspapers published the requirements for obtaining a card, requesting that readers cut out the text and check their applications for completeness in order to make the territorial officials' work easier. ${ }^{206}$ Due to the great demand expressed in readers' letters, newspapers such as the Croix $d u$ Congo published the decree again in full. ${ }^{207}$

What can we say about those whose application for immatriculation was crowned with success? Once again, it was the highly qualified and educated workers who made up the majority of successful applicants. Office workers in Léopoldville, where the colonial administration and many firms were based, formed the vanguard of this group, making up almost 50 percent of the immatriculated in the Belgian Congo by the end of $1954 .{ }^{208}$ The carte du mérite civique and immatriculation thus developed into means of distinction for office workers and public servants, with the individuals selected for these status categories most closely approximating the official ideal of the "genuine" évolué.

By contrast, the social group with the most comprehensive education and the closest contact with Europeans were not among the applicants: Congolese clergy. It is true that the decree on the carte du mérite civique promised that in theory "all natives of the Belgian Congo"209 could apply, but in practice Congolese clergy remained the absolute exception. This is particularly surprising given that the debate after the Second World War had already referred to them as the most assimilated group. ${ }^{210}$ This underrepresentation of clergy was politically intended. On 31 January 1949, in a letter to the provincial governors and missionrun institutions, the governor general explained why Congolese priests ought to refrain from applying: "It would seem to me a humiliation if they were to apply for the card. Their education and way of life effectively places them in a higher category and, in truth, makes them the assimilated avant la lettre."211

205 Letter from Pascal Mbaky to the district commissioner of Léopoldville, 18 January 1949; letter from district commissioner to Mbaky, 9 February 1949, AA/GG/19669.

206 "Carte du mérite civique, Karti ya lokumu,” Mbandaka 17 (11 September 1948): 1-2.

207 N.n., "Qui peut obtenir la Carte du mérite civique et comment faire pour l'obtenir," Croix du Congo (2 March 1952).

208 In total, there were 70 immatriculated at this point in time, of whom 32 were employed in the administrative service; Chambre des représentants, Rapport sur l'administration de la colonie du Congo Belge pendant l'année 1954 présenté aux chambres législatives (Brussels: Ministere des affaires africaines, 1955), 99. For 1950, see Le Parquet de première instance de Léopoldville: Liste des immatriculés de la province de Léopoldville, 1950, AA/GG/21256.

209 Ordonnance $\mathrm{N}^{\circ} 21 / 258$ AIMO du 12 Juillet 1948 créant une carte du mérite civique, reprinted in Voix du Congolais no. 30 (September 1948): 363.

210 Letter from the governor general to the provincial governors, 31 January 1949, AA/GG/15726. 211 Ibid. 
In the eyes of the colonial government, the clergy were already too assimilated for the carte du mérite civique and the application process was beneath their dignity. Furthermore, at this point in time plans for a reform of immatriculation granting more comprehensive legal assimilation were still being drawn up, with the clergy as a key target group. But in 1952, when immatriculation too failed to meet expectations and adhered to the same principle of selection as the carte du mérite civique, the colonial government advised Congolese priests not to seek this status either.

Belgian missionaries in the Congo were also sceptical about the immatriculation of Congolese brethren. The reasons emerge in correspondence between Gustaaf Hulstaert of Coquilhatville, missionary of the Sacred Heart of Jesus, and Antoine Sohier, head of the expert commission that had drawn up a system of immatriculation at the behest of the colonial minister. Sohier saw the Congolese priests as the true addressees of immatriculation. But shortly after the introduction of the status reform, Hulstaert pointed out that the immatriculation of clergy might have deleterious effects on their role in society. As a Flemish missionary and anthropologically active chronicler of vernacular groups, Hulstaert had a critical view of assimilation policy after 1945. He perceived the évolués as the gravediggers of indigenous language and culture. ${ }^{212}$ For him, the embrace of European society was synonymous with a turn away from the Congolese masses. With an eye on the situation in the metropole, Hulstaert reminded Sohier that in Belgium too the clergy were criticized for being closer to the bourgeoisie than to ordinary folk. ${ }^{213}$ Hence, according to Hulstaert, the African clergy ought to forego privileges and remain on the same level as the masses. Only in this way, he contended, would the priests be motivated to do their best to improve the lives of the population as a whole: "In my opinion it would beneficial for them to remain subject to indigenous law and authority, as this forces them to suffer injustices and harassment along with the ordinary people."214 Ultimately, this perspective on immatriculation spread among Congolese priests as well, who declared their wish to avoid alienation from their community. ${ }^{215}$ They remained subject to indigenous law.

212 H. Vinck, "Gustaav Hulstaert," in Biographie Belge d'Outre-Mer Belgische Overzeese Biografie, vol. 8, ed. Académie Royale Science d'Outre-Mer (Brussels: Librairie Falk fils, 1998); Hunt, "Rewriting."

213 Letter from Hulstaert to Sohier, 28 July 1952, reprinted in "Correspondence Sohier - Hulstaert (1933-1960)," Annales Aequatoria 18 (1997): 9-238.

214 Ibid.

215 Young, Politics, 84. 
The history of elite status in the Belgian Congo, then, includes several absurd chapters. The broad stratum of the detribalized, for whom the carte du mérite civique was intended, could not cope with the demanding selection procedure. And those for whom immatriculation was originally devised, namely the priests, opted not to apply for it. While the latter were regarded as too civilized, the former were seen as not civilized enough.

Based on several sets of annual statistics, we can at least make some selective statements, though no comprehensive ones, about the quantitative ratio of applications to successful outcomes. In the case of the carte du mérite civique we may work on the assumption that only one in three applications was successful. In 1953, for example, the figure was 59 out of 190 applications for the provinces of Léopoldville, Équateur and Orientale. ${ }^{216}$ The figures available for specific districts suggest the same ratio. Between 1948 and 1951, the committee in Lac Léopold II issued the carte du mérite civique to just one third of applicants. ${ }^{217}$

Similarly, when it comes to immatriculation, no more than 30 percent of applications were successful colony-wide in the first year. ${ }^{218}$ If we total up the colonial administration's official annual statistics for 1953 to 1956 and for 1958, this gives us a success rate of 46.6 percent , with 176 out of 378 applications being approved. ${ }^{219}$

Considering that it was first and foremost the educated and better-earning elite that contemplated applying for a change of status in the first place, the success rate must be described as meagre. In the first few years, this may still have been due to the General Government's particularly strict selection guidelines. The indications, however, are that the initial strategy of undercutting the resentment felt in the European milieu by limiting applications to "unassailable candidates" 220 became an entrenched, self-perpetuating process. In any case, the annual growth in holders of the carte du mérite civique and the immatriculated

216 Chambre des représentants, Rapport 1954, 99.

217 By that point the committee in Lac Léopold II had received just 12 applications: 4 were successful, 3 were rejected, and a decision was still to be made about the remaining 5; letter from the district commissioner to the provincial governor, 13 February 1950, AA/GG/15726.

218 On this percentage, see Mutamba-Makombo, Du Congo belge, 76.

219 On the statistics for these years, see Chambre des représentants. By way of comparison, in the French empire during the inter-war period the success rate for naturalization was 96 percent in the metropole, but just 61 percent in Indochina due to the strict selection process. See E. Saada, "Une qualité par degré. Civilité et citoyenneté en situation coloniale," in L'esclavage, la colonisation, et après. France, États-Unis, Grande-Bretagne, eds. P. Weil and S. Dufoix (Paris: PUF, 2005).

220 Letter from Van Hove to the colonial minister, 22 July 1949, AA/AI/4743/II/T/4. 
remained fairly constant. Between 1948 and 1955, an annual average of 126 cartes du mérite civique were issued. ${ }^{221}$ The number of those granted immatriculation was smaller still: an average of 36 a year. ${ }^{222}$

What was the total number of those allocated to these legal categories? The official data on this extend only until January 1959. By then, 1,557 cartes du mérite civique and 217 immatriculations had been granted. ${ }^{223}$ How many applicants there were, on the other hand, cannot be ascertained. But going by the success rates calculated above, the number of applicants will have been less than 5,000 for the carte du mérite civique and below 500 in the case of immatriculation.

Though the architects of colonial policy did not wish to create an elite through the carte du mérite civique, due to the strict selection procedures it soon stood for what immatriculation was supposed to imply: "a certificate of civilization."224 This prompted the Colonial Ministry to conclude that immatriculation must remain an exception: "We may expect this acknowledgment of civilization [the carte du mérite civique] to become the most highly coveted status and thus the associated procedure to be the most common one,"225 to quote one report.

We must bear in mind, however, that many applicants got neither a positive nor definitively negative answer, but instead had to exercise patience. Between 1955 and 1958, half of all applications for immatriculation resulted in a deferred decision, which was justified on the basis that more information was required about the candidates. ${ }^{226}$ The number of those who, after a brief or lengthy

221 Between 1956 and 1958, the average number of cards issued rose to 224. These figures are based on a list drawn up by Jean-Marie Mutamba-Makombo with the help of the annual administrative reports; Mutamba-Makombo, Du Congo belge, 78.

222 Ibid.

223 Chambre des représentants, Rapport sur l'administration de la colonie du Congo Belge pendant l'année 1958 présenté aux chambres législatives (Brussels: Ministere des affaires africaines, 1959), 104. The figures from this report are also cited in the relevant academic literature: De Schrevel, Les forces politiques, 152; Mutamba-Makombo, Du Congo belge, 78. It may be that due to a series of major events occurring in rapid succession, independence and the Congo crisis, no annual report for 1959 was produced in 1960. Nonetheless, we can glean from the press that the carte du mérite civique and immatriculation were still being applied for and granted here and there. The Voix du Congolais, for example, continued to publish announcements on current application processes: n.n., "Nos Avis. Immatriculation," Voix du Congolais no. 164 (November 1959): 686.

224 This wording appears in an internal document produced by the Colonial Ministry; Normes pour obtenir la carte du mérite civique, AA/AI/4743/II/T/4.

225 Carte du Mérite Civique, around the end of 1952, n.n., AA/AI/4743/II/T/4.

226 In this period there was an annual average of 101 delayed decisions for 242 applications; my calculations on the basis of the official annual statistics of the Chambre des représentants. 
wait, had to abandon the prospect of immatriculation for the time being, was smaller: on average, less than one in five was definitively rejected. ${ }^{227}$ Hence, the selection committees always left the door to elite status slightly ajar - in the belief that this prospect would spur on applicants to press ahead with their self-perfecting.

Measured against a total population of 13 million people, ${ }^{228}$ by the time of independence in 1960 the authorities had consistently appointed just a small number of individuals to the Congolese elite. If we tot up all holders of the carte du mérite civique and all the immatriculated, including their wives and children, we come to a figure of 2,325 individuals. The colonial state's appointment policy showed that not much more than 0.017 percent of the population were considered sufficiently civilized for membership of the elite.

As a result of the strict selection process, then, the door to elite status was open to just a small number of Congolese. While the applicants hoped to be let into the waiting room, for those permitted entry - through allocation to one of the two status categories - a new period of waiting began due to the only gradual process of legal equalization with Europeans. The vernacular elite's route to legal distinction and to recognition was not a direct or smooth one. It was more like an anxious circling: inside and outside the waiting room.

In several respects, appointment to the Congolese elite with the help of the carte du mérite civique and immatriculation was a source of disappointment. First, status reform was a delayed reform. The associated debate and political decision-making had dragged on for seven years, during which countless commissions and representatives of the colonial public sphere argued over the need for and scale of reform, with the various schemes repeatedly having to pass along the time-intensive official channels between metropole and colony. This tough process of negotiation ended in compromises that bore little resemblance to the initial demand for legal equality between Europeans and Congolese elite. In view of these thin pickings, in 1955, speaking before the Conseil Colonial, the missionary Joseph Van Wing, an ardent advocate of legal assimilation, referred to a "con"229 and an advertising campaign designed to placate the United Nations. But even after the introduction of the carte du mérite civique and immatriculation, interested parties had their patience tested. The appointment process was delayed by a time-consuming selection procedure. Time and again, before a decision could be reached new people had to be appointed to the selection

227 My calculations based on the official statistics for the years 1955, 1956 and 1958: Chambre des représentants.

228 This is the official figure for 1957; Mutamba-Makombo, Du Congo belge, 80.

229 Van Wing, quoted in Lemarchand, Political, 42. 
committees, meetings were postponed, new information was gathered about the candidates and they were advised to apply again at a later point in time. Furthermore, in case of a positive decision preparations had to be made for the awarding ceremonies and the new documents issued. As a result, it was not unusual for candidates to enquire about the progress of their applications: "I have the honour of requesting that you inform me of the answer to my letter of 26 January 1949 concerning my application for the Carte du Mérite Civique,"230 wrote Antoine Omari, who we have already met as a champion of évolué status, to the territorial administrator after an eleven-month wait. The polite phrasing barely conceals the Congolese elite's impatience to finally enjoy the privileges - however limited they may have been - that they claimed for themselves in view of their developmental accomplishments.

Second, through the strict selection of applicants, the status reform represented an attempt by the colonial administration to regain the prerogative of interpreting who or what the vernacular elite actually was, or ought to be. Certainly, through their ideal-typical self-portrayals as "genuine" évolués, Congolese authors had helped shape the prevailing interpretation of the elite. But colonial policy left the decision on membership of this elite to the committees, which subjected applicants to strict scrutiny of their lifestyle.

Outside the waiting room of colonial development, the committees were in a sense the doormen of elite-making policy, ensuring strict control of admissions. With a sceptical gaze, they scrutinized the supposed civilizational maturity of applicants, assessing this, among other things, in light of education, social behaviour, work ethic and loyalty to the colonial state. But when we consider that candidates most often failed due to an "irregular marital status," 231 it is clear that what the committees sought to create above all else was a moral elite, distinguished by monogamy, a nuclear family and the husband's fidelity. An évolué was a man whose family life complied with the bourgeois model of gender and Catholic moral values. The Congolese elite must not only wear a "white collar," but also have a "whiter than white" record. As a rule, the intimate investigations into applicants' private lives found what the committees were looking for: evidence of immorality. Ultimately, then, the selection committees certified that the majority of applicants were still insufficiently mature as évolués.

230 Letter from Antoine Omari to the head of the Service de la population noire in Léopoldville, 23 December 1949, AA/GG/19669.

231 As revealed by an internal document produced by the Colonial Ministry of 1956; Immatriculés et Porteurs de la Carte du mérite civique, AA/AI/4743/T/4. 
Due to a half-hearted status reform and the bureaucratic demonstration of applicants' imperfection, the promise inherent in the discourse of perfectibility, namely that the Congolese elite could ascend within colonial society through feats of cultural adaptation, lost some of its appeal. Authors writing for the Voix $d u$ Congolais increasingly questioned the selection committees' demand for a "perfected black": "Of course an évolué is not necessarily a perfect man. No country in the world has perfect people; it is not an attribute of this world. There is thus no reason for the government to demand this of us."232

Antoine Rubbens, the Elisabethville-based lawyer and an influential voice in the colonial public sphere, who had expressed opposition to special legal treatment for the évolués since 1945, made a new intervention in Katanga's leading daily, the Essor du Congo. Still at pains to put forward a supposedly factual critique, he rated this form of colonial maturity test as overblown: "The issue is being looked at in the wrong way if the native elite are being subjected to tests to establish their civility that the whites would struggle to pass." ${ }^{233}$ At the end of the day, the strict criteria suggest that Belgian colonial ideologues envisaged the Congolese elite as the extension of a colonial elite. This vernacular elite was supposed to stand out not so much through its educational qualifications as through an exemplary and morally impeccable lifestyle. In the inter-war period, however, many Europeans had failed to meet the requirements of a moral elite, as attested by reports of colonial politicians that expressed outrage, among other things, at their habitual drunkenness and sexual relationships with African women. ${ }^{234}$ The colonial authorities sought to counter the distorted image of the civilization-bringer, as many Europeans in the colony still articulated it, with an imaginary ideal of European civilization, which the officially appointed Congolese elite had not only to emulate but to embody. After the Second World War, the new vernacular elite were supposed to conduct themselves in the way Europeans were expected to do. Acquisition of the carte du mérite civique and immatriculation depended on whether candidates satisfied these requirements. Just like their European counterparts, however, those Congolese willing to adapt and eager to join the vernacular elite failed as flawless moral paragons. The difference was that, rather than accepting the deviation of Congolese from the ideal, the selection committees responded with sanctions, rejecting their applications or stripping them of elite status. While the colonial authorities regretted the discrepancy between moral discourse and lifestyle along Europeans,

232 L. Bongongo, "Pourqoui pas moi?,” Voix du Congolais no. 56 (November 1950): 652.

233 A. Rubbens, "La querelle de l'immatriculation," Essor du Congo (2 September 1950), reprinted in FEDACOL, L'opinion publique, 12.

234 See Lauro, "Politiques," 476-481; Lauro, Coloniaux. 
there is reason to believe that they furtively welcomed this gap when it came to Congolese.

This is because, third, the vernacular elite's failure in the eyes of the colonial state enabled Belgium to legitimize the delayed political integration of its colonial subjects at the United Nations. Furthermore, Brussels could use this argument to thwart the settlers' desire for political participation. A politically emancipated Congo was a world of the distant future.

Achieving immatriculation or obtaining a carte du mérite civique by no means guaranteed the Congolese elite the recognition they were battling to attain. The authorities failed to make good on the promise inherent in the colonial rhetoric of civilizing, namely that one could earn equal and dignified treatment by proving one's cultural bourgeoisification. The selection process, with its meticulous scrutiny of lifestyles; the permanent need to present the awarding committees with an impeccable image; the great risk of failure and, finally, the disillusionment felt in light of the actual benefits were all a great disappointment to the Congolese elite. After the Second World War, they had expected more from the recognition of their individual efforts to develop.

It was the enduring racist discrimination practised by European residents of the Congo that made a mockery of colonial elite-making. The constant insults and slights in everyday life and in press reports, the disregard of privileges as well as the resentment felt at the granting of equality to Congolese designated as equally civilized, all of this denied the elite the respectability for which they yearned. Rather than social recognition, legal status often brought public exposure. Hence, even the bourgeoisified évolués, who did everything they could to approximate the ideal cultivated in elite discourse, could not evade the disrespectful treatment to which Africans were exposed in the colonial situation per se.

The disappointment felt by the vernacular elite was of great importance to the process of internal decolonization. For in the eyes of this frustrated elite, right from the outset the propagandized vision of a Belgian-Congolese Community, which implied the coexistence of Europeans and Congolese on an equal basis, suffered from a lack of credibility. 